\title{
DEFENSE SPECIAL CASE TRANSURANIC WASTE
}
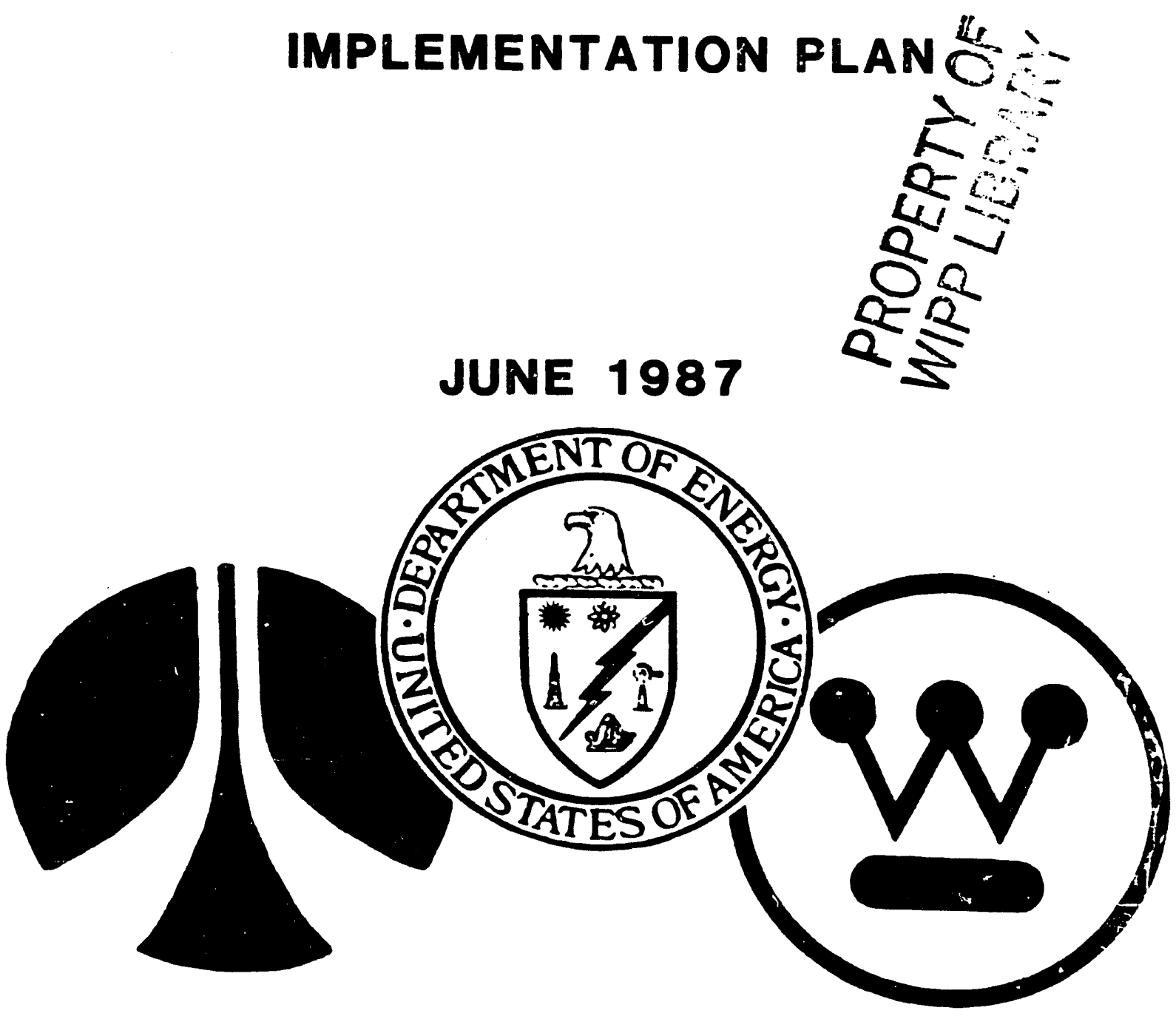

DEPARTMENT OF ENERGY

ROCKWELL INTERNATIONAL

WESTINGHOUSE

JOINT INTEGRATION OFFICE

ALBUQUERQUE, N.M. 
DISCLAIMER

This report was prepared as an account of work sponsored by an agency of the United States Government. Neither the their employees, makes any nor any agency thereof, nor any of assumes any legal ? iability or resp, express or implied, or accuracy any legal ?iability or responsibility for the apparatus, product that its use would not process disclosed, or represents Reference herein to infringe privately owned rights. process, or service any specific commercial product, or otherwise, does ny trade name, trademark, manufacturer, endorsement, recoimendation, or favity constitute or imply its States Government or any agency thering by the United opinions of authors any agency thereof. The views and state or reflect those of the hereiti is not necessarily any agency thereof. 
DOE/J IO- 022

DE 92000869

\section{DEFENSE SPECIAL CASE TRANSURANIC WASTE IMPLEMENTATION PLAN}

TRANSURANIC WASTE PROGRAM

JOINT INTEGRATION OFFICE

June 1987

Glenn D. Pierce

Rockwell International

Joint Integration office

and

Peter H. Carson

S. M. Stoller Corporation

\section{MASTER}


1.0 INTRODUCTION

1.1 DEFINITION

1.2 PURPOSE

1.3 GOALS

1.4 BACKGROLIND

2.0 CURRENT SITE PLANS

2.1 INEL

2.1.1 Waste Inventory

2.1.2 Current Plan

?.? ORNL

2.?.1 Waste Inventory

2.2.2 Current Plan

2.3 LANL

2.3.1 Waste Inventory

2.3.2 Current Plan

2.4 NTS

2.4.1 Waste Inventory

2.4.2 Current Plan

2.5 HANFORD

2.5.1 Waste Inventory

2.5.2 Current Plan

2.6 RFP

2.6.1 Current Plan

2.7 SUMMARY

3.0 POSSIBLE ALTERNATIVES TO SITE PLANS

3.1 INTRODUCTION

3.2 INEL

\subsubsection{Organic Setups}

3.2.2 Lead-Lined

3.2.3 Oversized Boxes

3.2.4 Miscellaneous SC Waste

3.3 ORNL

3.4 LANL

3.5 NTS

3.6 HANFORD

3.7 RFP

4.0 WORST CASE SCENARIO COSTS

5.0 ISSUES AND UNCERTAINTIES

5.1 INTRODUCTION

5.2 WASTE VOLUMES

5.3 MIXED WASTE

5.4 ATMX AVAILABILITY

5.5 TRUPACT CONFIGURATION 


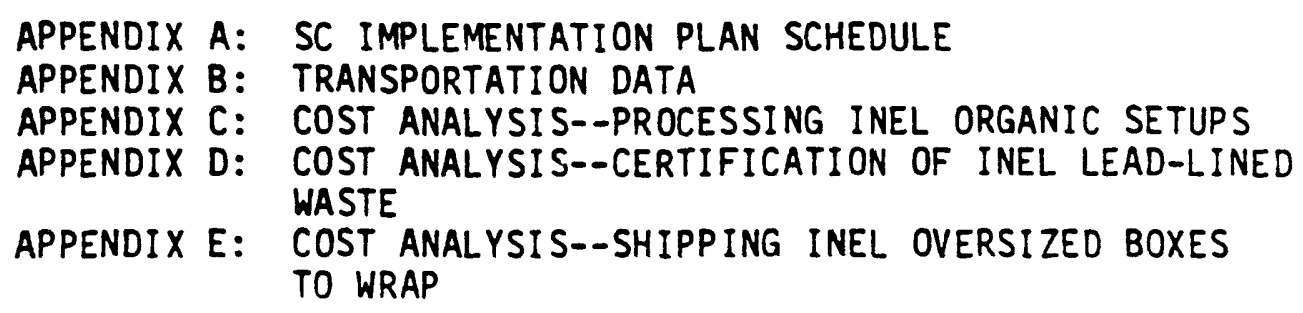




\section{LIST OF TABLES}

TABLE 2-1 INEL SC Waste Inventory

2-2 ORNL SC Waste Inventory

2-3 LANL SC Waste Inventory

2-4 NTS SC Waste Inventory

2-5 Hanford SC Waste Inventory

2-6 Site Plan Summary

3-1 Organic Setup Cost Summary

3-2 Lead-1 ined Cost Summary

3-3 Oversized Box Cost Summary

6-1 Summary of Recommendations

B-1 Truck Freight Costs for Shipping TRU Waste

C-1 Cost Sumary--Alternative Processing Strategies

for INEL Organic Setups

\section{LIST OF FIGURES}

FISURE 3-1 Special Case Logic Flow Diagram

Figure 4-1 Life Cycle llanagement Cost for

FIGURE A-1 SC implementation Plan Schedule 


\section{EXECUTIVE SUMMARY}

\section{PURPOSE}

The purpose of the Special Case Implementation Plan (SCIP) is to establish a comprehensive plan for the efficient long-term management and disposal of defense special case (SC) transuranic (TRU) waste. To fulfill this purpose, a review of SC waste management strategies (at both the site-specific and TRU program levels), waste characteristics and inventories, processing and transportation options, and disposal requirements was made. This review provides a plan for implementing policy decisions and useful information for making those decisions.

The SCIP is intended to provide a baseline plan to which alternate plans can be compared. General potential alternatives are provided for future consideration when data concerning facility availability and costs are better defined. Milestones for the SC Implementation Plan are included in Figure 1, which summarizes milestones for each SC waste site. The cost of implementing the SC program has an upper limit of $\$ 89$ million for the worst case scenario. The actual cost of implementation could be dramatically lower than the worst case figure.

\section{BACKGROUND}

Special case transuranic wastes are those stored TRU wastes defined by individual DOE-managed sites as being impractical to-certify to the WIPP Waste Acceptance Criteria (WAC). Special case wastes are not defined by absolute physical measurements. The definition is based on management judgement that the cost, exposure, or environmental impact of retrieving, processing, packaging, and certifying the waste with current or planned capabilities at a site is unacceptably high. Synonyms for special case wastes are "difficult to certify wastes" and "impractical to certify wastes."

Based cn the final Inventory Workoff Plans (IWOPS), 5 io $10 \%$ of all stored TRU waste is classified as special case. The majority of the identified SC TRU volume is in storage at INEL, with small amounts at Hanford, Los Alamos National Laboratory, Dak Ridge National Laboratory, 


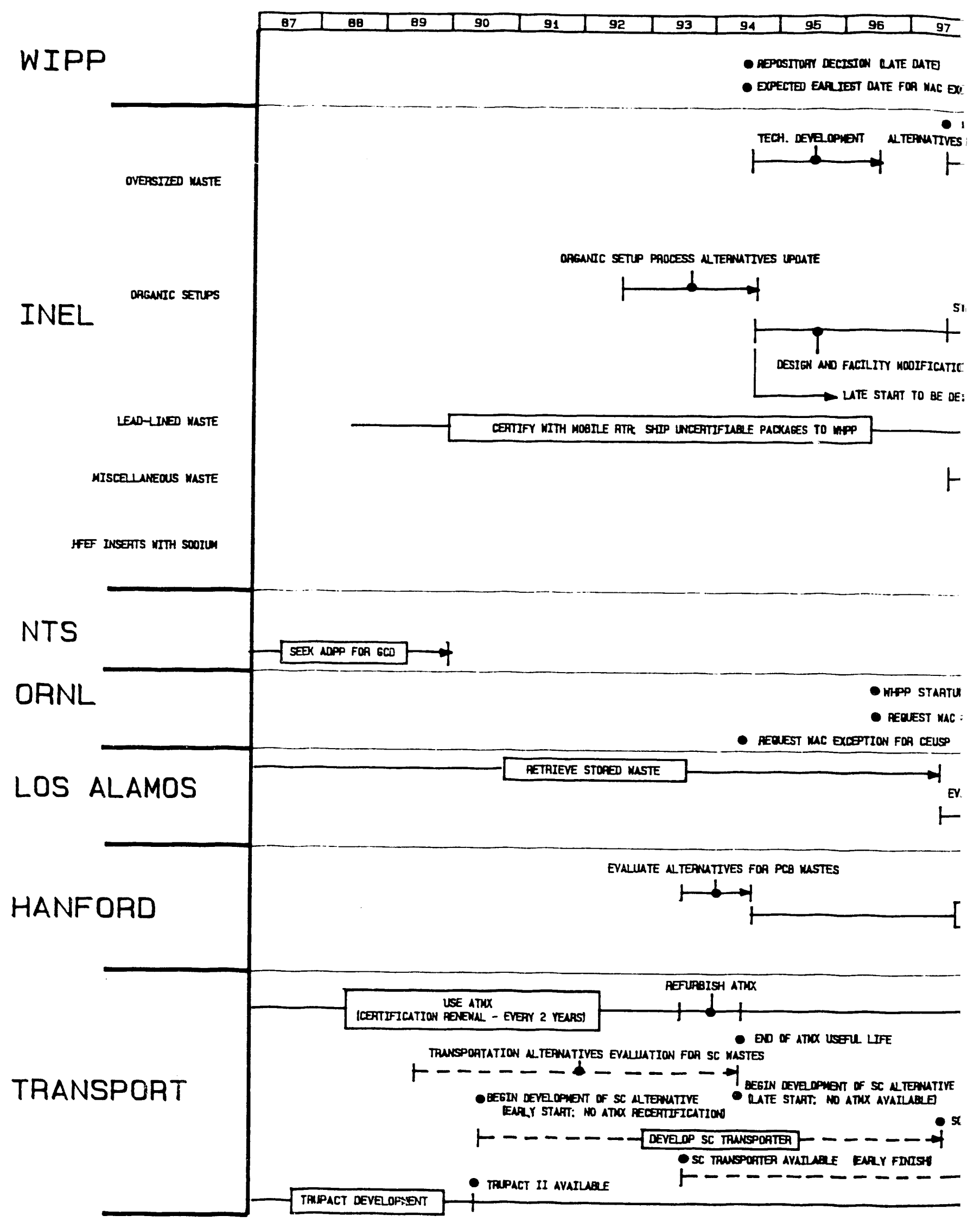

FIGURE 1: SC II 


\begin{tabular}{|l|l|l|l|l|l|l|l|l|l|l|l|l|l|l|}
\hline 98 & 99 & 00 & 01 & 02 & 03 & 04 & 05 & 06 & 07 & 08 & 09 & 10 & 11 & 12 \\
\hline
\end{tabular}

PTION

TEST TRUNSPORT AVATUAE DATE

VNULUTION FOR OVERSTZED MASTE

$1+1$

STIE REDUCTION AT WPAP

$-\infty$ -

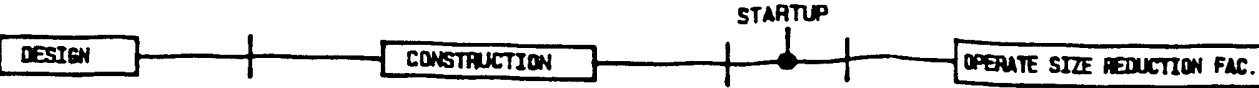

inTuP

1

FAINED

- ine complete stofed maste fetaieval

MLTERATIVES EVALUATION FOR MISC. MASTE

$\stackrel{1}{1}$

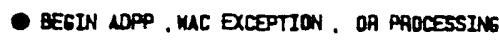

NLTERUTIVES EVALUATION FOA HFE INSERTS

$+$

PRUCESS TO NEET MIPP MAC

KCPPION FOA MASTE IN STAIRLESS STEE WULS

MISC. CAN MASTE

JATE SC NLTENMTIVES

MATE SC

- intute anpo of exception heduest if heouiped

IPLENENT PCB SELECTED ALTERUTIS

- map complete - SIzE heduction aVatuale

- REQUEST MAC EXcoptION For HIEH FISSILE MASTES

USE REUPEISHED ATN

TRUSPORTE AVAIUALE MATE FDISS

SC TRUSPPQATEA OPEATIONS

MPACT OPERATIONS

\section{IPLEMENTATION PLAN SCHEDULE}


and the Nevada Test Site. Examples of SC TRU wastes include oversized containers, waste forms with excessive amounts of dispersible particulates, wastes contaminated with PCBS, and lead-lined containers. Also, classified TRU waste is included in this report because special handling is required to certify the waste for WIPP disposal. Detailed descriptions of waste volumes and characteristics for each site are presented in section 2 of this plan.

The overall goals for long-term management of SC TRU wastes are:

1. End generation of additional SC TRU wastes;

2. Cost-effectively certify as much SC TRU as possible for permanent disposal in WIPP;

3. Implement alternate practices to achieve permanent disposal of noncertifiable wastes at site(s) other than WIPP.

\section{SITE PLANS}

Currently six sites generate or store SC TRU waste: the Idaho National Engineering Laboratory (INEL), the Oak Ridge National Laboratory (ORNL), the Nevada Test Site (NTS), the Los Alamos National Laboratory (LANL), Hanford, and the Rocky Flats Plant (RFP).

INEL

INEL has ident if ied $3558 \mathrm{~m}^{3}$ of SC waste, the largest volume of stored $S C$ waste of any DOE site. In addition to the above waste, identified in the INEL IWOP (Ref. 1), Argonne National Laboratory - West (ANL-W) has identified 81 Hot Fuel Examination Facilities inserts as SC waste.

INEL plans to modify the existing Process Experimental Pilot Plant facility, build a size reduction facility, and use the mobile Nondestructive Analysis/Nondestructive Examination facility to certify its SC waste. The ANL-W SC waste is in safe interim storage. The current plan is to continue interim storage until $A N L-W$ develops the capability to make the waste certifiable. 
ORNL

ORNL has ident ified $1274 \mathrm{~m}^{3}$ of waste as SC waste. ORNL is now planning to build the Waste Handling Pilot Plant to certify the majority of its SC waste. ORNL is also pursuing the possibility of WIPP WAC exceptions with the Waste Acceptance Criteria Certification Comittee for a small amount of SC waste.

LANL

LANL has $145 \mathrm{~m}^{3}$ of SC waste. LANL plans to dispose of this waste on site using Greater Conf inement Disposal technology.

NTS

NTS currently indicates that it has $289 \mathrm{~m}^{3}$ of SC waste. The current plan is to dispose of this waste via Greater Conf inement Disposal.

Hanford

In its final IWOP (Ref. 2) Hanford has ident ified $2.5 \mathrm{~m}^{3}$ of SC TRU waste consisting of 12 drums of material that was used during critical mass studies. In addition to the SC waste in the IWOP, Hanford has 5 $\mathrm{m}^{3}$ of PCB-contaminated TRU waste and $180 \mathrm{~m}^{3}$ of classified TRU waste.

The PCB-contaminated waste is not considereed So waste by Hanford, but is included in this report because the waste will require the same processing as INEL organic setups.

Hanford plans to ship the critical mass studies waste to WIPP under an exception to the WIPP WAC. The PCB-contaminated waste will be certified in an off-site facility and the classified waste will be declassified and certified in the Waste Receiving and Processing (WRAP) facility.

\section{RFP}

RFP is planning to declassify all of its classified TRU waste so that the waste can be shipped to WIPP.

\section{SUMMARY OF RECOMMENDATIONS}

A summary of the waste volumes, facility requirements, scheduled start dates, facility capital costs, and processing costs required to implement the site plans is shown in Table 1. 
TABLE 1

Site Plan Summary

\section{Site \\ INEL \\ Organics \\ RH/Lead-Lined \\ Oversized Boxes \\ Miscellaneous \\ HFEF Inserts \\ Total}

ORNL

RH

CEUSP

Misc. Cans

S. S. Wells

Total

LANL

Oversized Waste

NTS

Oversized Boxes

Uncert. Drunis

Classified TRU

Total

Hanford (3)

Drums-high fissile

Class if ied

Drums-PCB $(4)$

Tota 1

\section{Volume (m3) Requirements}

\section{3}

114

862

919

15

3573
1270 WHPP
1.7 WIPP WAC Excention
0.3 WIPP WAC Exception
1.5 WIPP WAC Exception 1274

Modified PREPP

Mobile NDA/NDE

Size Reduction Fac.

Size Reduction Fac.

Pyrophorics Removed

145 ADPP

$\begin{array}{rr}57 & \text { ADPP } \\ 48 & \text { ADPP } \\ 184 & \text { ADPP } \\ 289 & \end{array}$

FY 1989

FY1989

FY 1987

FY 1996

FY1994

FY 1994

FY1999

FY 1997

$$
\begin{aligned}
& 0 \\
& 0
\end{aligned}
$$$$
48.0
$$

48.0

$\begin{array}{cc}T B D(2) & \text { TBD } \\ 7.6 & \text { TBD } \\ 7.4 & \text { TBD } \\ 0 & \text { TBD } \\ \text { TBD } & \text { TBD } \\ 22.2 & \text { TBD }\end{array}$

Start Facility Processing(1)
Date (SMillion)

(sMillion) (slitllion)
17

0

0

0

17

0.3
TBD

TBD

TBD

TBD
2.5 WIPP WAC Exception 180

5

188
FY 1999

FY1997

Off-site incinerator FY1997

TBD -TO Be Determined

ADPP - Alternate Disposal Practices Petition

(1) - Total life cycle processing costs.

(2) - INEL estimates the cost to be no higher than $\$ 7$ million. The actual cost will depend on the outcome of negotiations between INEL and the EPA concerning feed sampling requirements.

(3) - Zero facility costs are shown for WRAP because the facility will be primarily a non-special case $\mathrm{CH}$ certification facility and will be built regardless of its role as an SC facility.

(4) - Not considered SC TRU waste by Hanford but shown because it will require the same processing as the INEL organic setups.

Alternatives to the site plans were examined. In several cases, the alternatives proved to be potentially more cost-effective than the plan proposed by the site. The cost analyses are shown in Appendices $C, D$, and $E$. The recommendations that were drawn from the analyses are summarized in Table 2. 


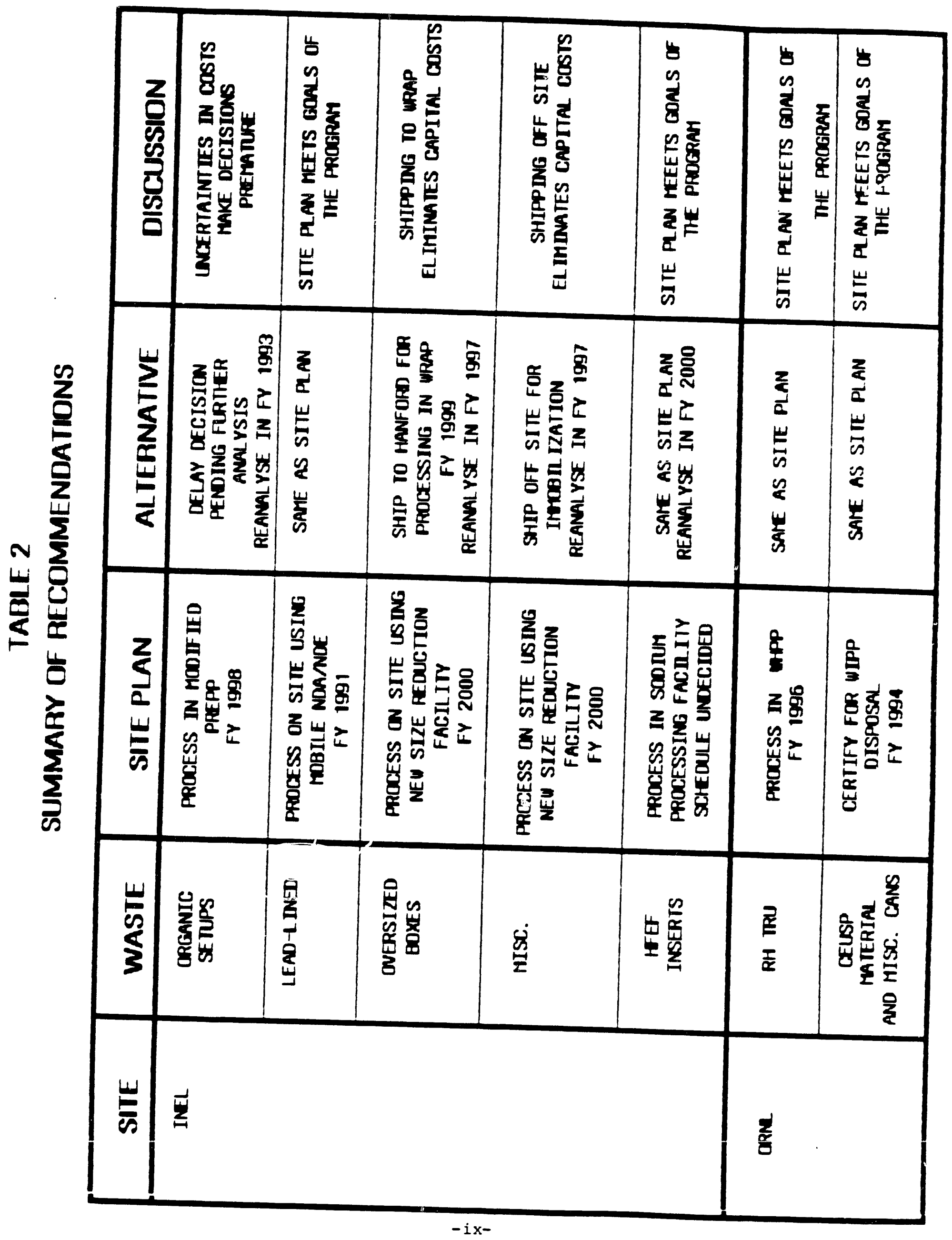




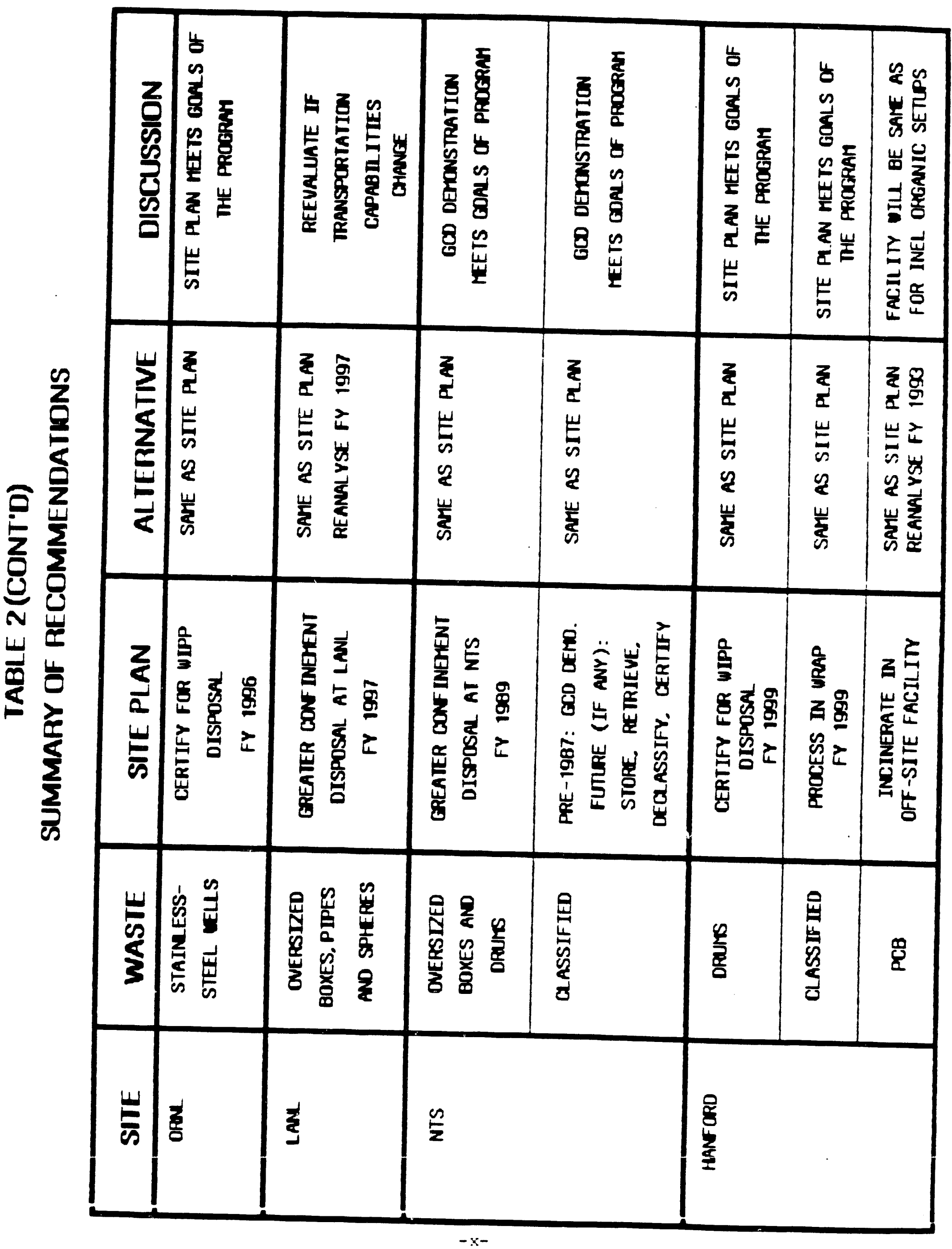




\subsection{INTRODUCTION}

\subsection{DEFINITION}

Wastes that are now called special case (SC) wastes have in the past been called "difficult to certify wastes" and "impractical to certify wastes." The SC waste category has no quantitative definition, but rather consists of wastes that site waste management organizations deem impractical to certify. The determination that wastes are impractical to certify is made on the basis that the cost, exposure, or environmental impact of retrieving, processing, and certifying is unacceptably high given the current or planned capabilities of the site. Examples of SC waste include oversized containers, wastes contaminated with more than 50 ppm of polychlorinated biphenyls (PCBS), and lead-lined containers. Classified TRU waste is also included in this report due to the special processing requirements needed to declassify the waste. Specific SC inventories are provided in Section 2.

\subsection{PURPOSE}

The purpose of the Special Case Implementation Plan (SCIP) is to provide a comprehensive strategy for permanently disposing of SC transuranic (TRU) wastes. This plan describes a program to reduce the Defense Transuranic Waste Program's dependency on the SC classification by influencing facility design so that sites will be capable of certifying more waste forms. The expanded facility capabilities will reduce the volume of SC waste because such wast! will no longer be impractical to certify. The SCIP is intended to privide a baseline plan for SC waste management. Milestones for the plan are provided in Appendix $A$. Alternate management strategies will be evaluated against the baseline as facility availability and cost data are available.

\subsection{GOALS}

The goal of the Defense Transuranic Waste Program is to end interim storage of TRU waste and to permanently dispose of this waste in a safe and cost-effective manner. The favored method for disposing of stored TRU waste is deep geologic emplacement in the Waste Isolation Pilot Plant $(W I P P)$. 
The goal of the Special Case Implementation Plan is to develop a system that will certify all SC waste for WIPP emplacement. Alternate disposal techniques will be used as a method of last resort.

\subsection{BACKGROUND}

The Defense Waste Management Plan established a system for ending interim storage of defense radioactive waste and emplacing it in WIPP. The Plan intended that all stored TRU waste be certified for WIPP emplacement, and this is still the goal of the Defense Transuranic Waste Program. As much defense TRU waste as possible will be disposed of in WIPP.

DOE Order 5820.2 established that site management can classify some TRU waste as "impractical to cert ify." DOE Order 5820.2 allows DOE field offices, in consultation with DOE Headquarters, to establish alternate site-spec if ic TRU waste management practices. This order also states that small amounts of waste that do not comply with the WIPP Waste Acceptance Criteria (WAC) may be accepted in the WIPP on a case-by-case basis through a controlled review and approval process under the direction of the WIPP Project Office and the WIPP Waste Acceptance Criteria Certification Committee. The WIPP Project office has stated that it anticipates that no waste will be disposed of under an exception ruling until the decision to corivert WIPP to a permanent repository has been made. This decision will follow the end of the demonstration period.

The process of developing an alternative to disposal. at WIPP first requires the sites to characterize their TRU waste. This waste characterization was completed in FY86, when each of the storage sites prepared a final Inventory Work off Plan (IWOP) (Refs 1, 2, 3, 4, \& 5). These documents presented the waste volumes, characteristics, and the sites' plans for permanently disposing of the waste. The next step in developing an alternative is to analyze several alternate disposal practices (ADP) with regard to radiation safety, health protection, environmental protection, economics, resource commitments, and regulatory compliance. The ADPs are formally evaluated in an Alternate Disposal Practice Petition (ADPP). The ADPP provides a common basis for 
management decisions and facilitates communication between DOE Headquarters and the DOE field offices. The ADPP evaluation process identifies one of the ADPs as being the best alternative and approves it as an acceptable disposal practice.

The ADP forecasted to be approved is a technique called Greater Confinement Disposal (GCD). $G C D$ is a technique for disposal of waste that uses natural and/or engineered barriers to provide a degree of isolation greater than that of shallow land burial but possibly less than that of a geologic repository. Technical support for this type of alternate disposal has been developed at the Oak Ridge National Laboratory (ORNL), the Nevada Test Site (NTS), and the Idaho National Eng ineering Laboratory (INEL).

Any waste that is disposed of on-site will be subject to all applicable environmental regulations and applicable DOE Orders. The applicable regulations are those that implement the Clean Air Act, the Clean Water Act, the Toxic Substance Control Act (;SCA), the Superfund Amendments and Reauthorization Act, the Resource Conservation and Recovery Act (RCRA), the Comprehensive Environmental Response, Compensation and Liability Act (CERCLA), the National Environmental Policy ACt, and EPA Regulation 40 CFR 191. Each of the storage sites must work with the responsible EPA regional office and its state to determine which regulations will be applied to its waste sites. DOE Orders 5820.2 and 5490.3 govern the disposal and movement of these wastes.

Currently, six sites generate or store SC waste: INEL, ORNL, NTS, LOS Alamos National Laboratory (LANL), Hanford, and the Rocky Flats Plant (RFP). SC waste volumes, waste characteristics, and waste management plans, as provided by each site, are presented in Section 2 . Section 3 presents the system wide implementation plan in which alternatives to the site plans are analyzed. A worst case cost analysis is presented in Section 4. Issues and uncertainties are discussed in Section 5 and a summary of recommendations is shown in section 6 . 


\subsection{CURRENT SITE PLANS}

\subsection{INEL}

\subsubsection{Waste Inventory}

INEL has the largest inventory (by volume; see Table 2-1) of SC waste of any UOE site. Four types of SC waste have been identified: organic setups, lead-lined drums, oversized packages, and miscellaneous uncertifiable packages.

In addition to the above SC wastes, Aryonne idational Laboratory - West (ANL-W) has identified 81 Hot Fuel Examination Facility (HFEF) inserts (approximately $15 \mathrm{in}^{3}$ ) as SC waste. These inserts contain Rit waste contaninated with elemental sodium. Elemental sodium does not meet the WIPP WAC Decause it is a pyropnoric material.

Uryanic setups constitute the majority of INEL'S SC waste. These are uryanic liquids that have been mixed with calcium silicate to form a paste-like material. Over 7,000 of these packages are designated as SC waste due to suspected presence of PCBs or excessive free liquids, which do not meet WIPP WAC. PCBS cannot be disposed of in WIPP because they are TSCA regulated sudstances and WIPP is not permitted as a TSCA disposal site.

The lead-lined packages are considered SC because they are not certifiable in the Stored Waste Examination Pilot Plant (SWEPP). The Real-Time Radioyraphy system in SWEPP is not powerful enough to penetrate the lead-lined packages. Also, some of these containers may contain waterials that do not meet the WIPP WAC.

The oversized boxes are packages that exceed the standard $4^{\prime} \times 4^{\prime} \times 7^{\prime}$ or $4^{\prime} \times 5^{\prime} \times 0^{\prime}(W \times H \times L)$ size. boxes that exceed this size are too larye to be processed in the Process Experimental Pilot Plant (PREPP) and some are also too larye to fit into the Transuranic Package Transporter (TRUPACT), 
which is the designated transportation system for shipping contact-handled (CH) waste to WIPP. Also, there is a concern that these boxes may have lost container integrity while in storage.

The miscellaneous waste consists of a variety of waste types that require immobilization to be certified. These waste types include small quantities of uncemented resins, liquid mercury, and pump oil.

INEL SC waste inventories are shown in Table 2-1.

TABLE 2-1

INEL SC Waste Inventpry

(As of 12/31/85) (1)

\begin{tabular}{|c|c|c|c|c|}
\hline & Waste Type & Packages & $\begin{array}{l}\text { Waste Vol./ } \\
\text { Pkg. }\left(\mathrm{m}^{3}\right)\end{array}$ & $\begin{array}{l}\text { Total } \\
\text { Vol. }\left(\mathrm{m}^{3}\right)\end{array}$ \\
\hline & $\begin{array}{l}\text { Organic Set ups } \\
\text { Drums ( } P C B) \\
\text { Drums (free liquid) } \\
4^{\prime} \times 4^{\prime} \times 7 \text { ' Boxes } \\
\text { tota } 7\end{array}$ & $\begin{array}{r}7121 \\
700 \\
12 \\
7833\end{array}$ & $\begin{array}{l}0.208 \\
0.208 \\
3.0\end{array}$ & $\begin{array}{r}1481 \\
146 \\
36 \\
1663\end{array}$ \\
\hline & $\begin{array}{l}\text { Lead- } 1 \text { ined } \\
\text { Drums } \\
4^{\prime} \times 4^{\prime} \times 7^{\prime} \text { Boxes } \\
\text { total }\end{array}$ & $\begin{array}{r}446 \\
7 \\
453\end{array}$ & $\begin{array}{l}0.208 \\
3.0\end{array}$ & $\begin{array}{r}93 \\
21 \\
114\end{array}$ \\
\hline & $\begin{array}{l}\text { Oversized Boxes } \\
\text { Non-Standard Boxes } \\
\text { Over-Weight Boxes } \\
\text { total }\end{array}$ & $\begin{array}{r}101 \\
1 \\
102\end{array}$ & $\begin{array}{l}8.5(2) \\
3.0\end{array}$ & $\begin{array}{r}859 \\
3 \\
862\end{array}$ \\
\hline & $\begin{array}{c}\text { iliscellaneous } \\
\text { Resins }\end{array}$ & & & \\
\hline & $\begin{array}{l}\text { Drums } \\
\text { M III Bins } \\
4^{\prime} \times 4^{\prime} \times 7^{\prime} \text { Boxes } \\
\text { total } \\
\text { Mercury }\end{array}$ & $\begin{array}{r}42 \\
264 \\
1 \\
307\end{array}$ & $\begin{array}{l}0.208 \\
3.40 \\
3.0\end{array}$ & $\begin{array}{r}9 \\
898 \\
3 \\
910\end{array}$ \\
\hline & $\begin{array}{l}\text { Drums } \\
\text { Pump } 0 i 1\end{array}$ & 28 & 0.208 & 6 \\
\hline & $\begin{array}{l}4^{\prime} \times 4^{\prime} \times 7^{\prime} \text { Boxes } \\
\text { total }\end{array}$ & $\begin{array}{r}1 \\
336\end{array}$ & 3.0 & $\begin{array}{r}3 \\
919\end{array}$ \\
\hline & HFEF Inserts & 81 & 0.18 & 15 \\
\hline & TOTAL & 8805 & & 3573 \\
\hline (1) & $\begin{array}{l}\text { Data from the INEL IWOP } \\
\text { This is an average volume }\end{array}$ & $\begin{array}{l}\text { (Ref. I) } \\
\text { e for these } \\
-5-\end{array}$ & boxes. & \\
\hline
\end{tabular}




\subsubsection{Current Plan}

DOE has documented that it will not leave any TRU waste on the INEL site (Ref 6). INEL is planning to process all of its stored SC waste for emplacement at WIPP, and has proposed modifications to PREPP that will enable it to process the organic setups to meet the WIPP WAC. The cost is estimated to be no more than $\$ 7$ million (Ref 7 ) for equipment modifications and for permitting PREPP as a hazardous waste incinerator, as regulated by RCRA, and for PCB incineration, as regulated by TSCA. The actual cost will depend on results of negotiations between INEL and the Environmental Protection Agency (EPA) concerning feed sampling and control. Processing of this waste is scheduled to begin in FY98.

INEL current ly plans to cert ify as much of its lead-lined waste as possible using the mobile remote-handled (RH) assay system being developed by LANL (Ref 8 ). This system will have a high-energy Real-Time Radiography system capable of examining dram contents through the lead lining. Any packages that the mobile system cannot certify will be shipped to ORNL in accordance with Department of Transportation regulations, for processing in the Waste Handling Pilot Plant (WHPP). This will be necessary because INEL has no capability to process RH waste. The lead-lined drums have contents that would be considered RH waste if they were not shielded. The high dose rates of the unshielded contents (greater than $200 \mathrm{mrem} / \mathrm{hr}$ ) prevent this waste from being processed in PREPP. INEL will begin design efforts in FY88 and will operate the facility through 1995.

To be cert if ied for WIPP emplacement, the oversized packages must undergo nondestructive assay/nondestructive examination (NDA/NDE). These packages are too large to be certified in SWEPP and tho se that require processing are too large to be accepted in PREPP. Also, approximately $40 \%$ of the oversized containers are too large to be transported in TRUPACT. INEL is proposing that a size reduction facility be built at INEL. This new facility would utilize the mobile NDA/NDE equipment being developed at LANL, and would allow INEL to repackage this waste into containers that are transportable in TRUPACT and acceptable at WIPP. The estimated cost of this facility is $\$ 7$ million (Ref 7 ). Processing of this waste is scheduled to begin in the year 2000 and will cont inue through 2013 . 
The majority of the miscellaneous SC packages requires immobilization to meet the WIPP WAC. The method for immobilization is different for each of the waste types. INEL is proposing that the waste be processed in the same facility that they are recommending for the oversized waste. Adding the capability to immobilize waste in the size reduction farility would dllow the waste to be processed on-site and it would give INEL the flexibility to process any other uncertifiable waste that may be found during retrieval operations. This waste will be certified beginning in the year 2000 .

The HFEF inserts will require processing to chemically stabilize the elemental sodium. ANL-W plans to continue safe interim storage until funding is acquired to build and operate a sodium processing facility on that site. In additional to certifying the TRU waste this facility will also stabilize all of ANL-W's $500 \mathrm{~m}^{3}$ of $10 \mathrm{~N}$-level sodium waste.

\subsection{ORNL}

\subsubsection{Waste Inventory}

In their final Inventory Work off Plan (Ref 3), ORNL listed $1274 \mathrm{~m}^{3}$ of R.4 waste as SC waste that is expected to be certifiable for WIPP emplacement. The waste has been stored in metal cans, underground storage tanks, and concrete casks. ORNL's SC waste can be divided into four categories: RH TRU waste retrievably stored in the 7855 building and trenches in Solid Waste Storage Area 5, and RH TRU sludges stored in undergound tanks; Consolidated Edison Uranium Solidification Project (CEUSP) uranium oxide-containing cans; miscellaneous cans; and encapsulated material stored in stainless steel wells.

RH TRU waste has been listed as SC waste because there was no way to certify it. It will be dropped from the next SC inventory since the WHPP will be built and the waste can be certified for WIPP disposal.

The CEUSP material contains uranium oxide and other chemical salts that do not currently meet the WIPP WAC due to high fissile material content. 
The miscellaneous cans also contain mixed uraniun oxides, but are from a variety of sources including Hanford, the Savannah River Plant, Argonne National Laboratory, and LANL. The materials in these cans are not solidified and could pose a significant immobilization problem. The generator is considering solidifying these materials in similar fashion to the CEUSP materials.

The encapsulated material stored in the stainless steel wells has fissile material quantities that exceed the WIPP WAC.

ivaste inventories are shown in Table 2-2.

TABLE 2-2

ORNL SC Waste Inventory (as of $12 / 31 / 85$ ) $(1)$ r

$\begin{array}{lll}\text { Waste Type Packages } & \text { Waste Vol.l Total } \\ \text { Pkg. }\left(\mathrm{m}^{3}\right) & \text { Vol. }\left(\mathrm{m}^{3}\right)\end{array}$

RH TRU

Sludges (drum equivs.) $4579 \quad 0.208 \quad 953$

Concrete Cask 4"

Concrete Cask 6"

95

0.995

95

Cancrete Cask 12"

212

0.995

total

32

0.329

211

4918

11

1270

CEUSP

$\begin{array}{llll}3.75 " \times 24.625 " \text { Cans } & 401 & 0.0042 & 1.7\end{array}$

Miscellaneous Cans

$3.5^{\prime \prime} \times 10^{\prime \prime}$ Cans

200

0.0016

0.3

Stainless Steel Wells
Capsules (2)

13

0.113

1.5

TOTAL

5532

1274

(1) Data provided by the ORNL IWOP (Ref 3)

(2) As indicated in the 1987 ORNL Integrated Data Base submission, this volume may rise to $6.8 \mathrm{~m}^{3}$. The increased volume does not change the conclusions of this document. 


\subsubsection{Current Plan}

ORNL is planning to certify all of its RH TRU waste for WIPP

emplacement. This waste will be processed in the WHPP when it comes on line in 1996. WHPP will provide capabilities to examine the retrieved waste, repackage and process it as necessary, and certify that it meets the WIPP WAC.

The CEUSP material and the miscellaneous cans of uranium oxides, if solidified, will possibly be disposed of in WIPP. This material could be cert if ied for WIPP emplacement through agreement with the WAC Certification Committee, the WIPP Project Office, WIPP Operations, and the state of New Mexico that safety is assured even though this waste exceeds the WIPP WAC on fissile material. For any remaining waste, transfer will be sought to the Federal Waste Management system (FWMS). ORNL will seek the exception by FY94.

ORNL will seek to dispose of the encapsulated waste stored in the stainless-steel wells in WIPP. This will require an exception to the WIPP WAC. If the exception is not granted, then a transfer of responsibility to the FWMS will be sought. The exception will be sought in FYg6.

In summary, ORNL does not expect to have any SC TRU waste to dispose of. Host of the waste that is currently listed as SC waste will be certified as RH waste for WIPP emplacement. The remaining waste will become the responsibility of the FWMS.

\subsection{LANL}

\subsubsection{Waste Inventory}

LANL has ident ified small quanitities of both $\mathrm{CH}$ and $\mathrm{RH}$ waste as impractical to certify. The $\mathrm{CH}$ waste consists primarily of pieces of large, heavy equipment and machine tools that cannot be processed in the Size Reduction Facility. This waste is stored in seven boxes that are in retrievable storage. 
LANL has ident if ied four experimental spheres with 6' diameters as SC waste because there is no approved way to transport them to WIPP. The spheres have two-inch thick walls, weigh approximately $8000 \mathrm{lbs}$, and cannot be processed in the Site Reduction Facility due to facility weight limitations of 4000 ibs.

The RH waste that has been ident if ief as SC waste is composed of a variety of different waste forms. Eleven casks that are 2 ' in diameter and 9.5' long are expected to be overpacked in the RH long Canister. These wastes are listed as SC waste due to uncertainties in LANL's ability to overpack the casks in an $\mathrm{RH}$ canister and certify them for WIPP disposa 1.

The remainder of the $\mathrm{RH}$ waste that is impractical to certify is stored in stee $1 /$ concrete casks that are too large to $f$ it in the RH transportation cask. The majority of these casks contain ${ }^{-} 2 H$ waste which was placed into 2' diameter, 15' long steel pipes. The waste was then immobilized in concrete. This configuration makes any potential repackaging operation difficult and the 15' long pipes are too long for transport to WIPP.

One of the casks contains part of the Los Alamos Molten Plutonium Reactor Experiment reactor. This material is stored in a $2.5^{\prime}$ diameter, $15^{\prime}$ long steel cask and is immobilized in concrete. The waste contains a small amount of elemental sodium, a pyrophoric material, which does not meet the WIPP WAC.

LANL SC waste volumes are shown in Table 2-3.

\subsubsection{Current Plan}

LANL has identified three options for disposing of its SC waste. They are: 1) disposing of the waste on-site; 2) making special arrangements with the WAC Certification Comittee for permanent disposal at WIPP; and 3) opening and repackaging the waste. 
TABLE 2-3

LANL SC Waste Inventpry

(as of 12/31/85) (1)

\begin{tabular}{|c|c|c|c|}
\hline \multicolumn{2}{|c|}{ Packages } & \multirow{2}{*}{$\begin{array}{l}\text { Waste Vol.l } \\
\text { Pkg. }\left(\mathrm{m}^{3}\right)\end{array}$} & \multirow{2}{*}{$\begin{array}{l}\text { Total } \\
\text { Vol. }\left(\mathrm{m}^{3}\right) \\
104\end{array}$} \\
\hline $\begin{array}{l}\text { CH Waste } \\
\text { Non Standard Box }(2)\end{array}$ & 7 & & \\
\hline Experimental Spheres & 4 & 3.2 & 13 \\
\hline \multicolumn{4}{|l|}{ RH Waste } \\
\hline $\begin{array}{l}\text { Stee l/Concrete Casks } \\
21 \text { 'dia. } \times 9.5 \text { 'long }\end{array}$ & 11 & 0.898 & 10 \\
\hline $\begin{array}{l}\text { Stee } 1 / \text { Concrete Casks } \\
2 \text { 'dia. } \times 15 \text { 'long } \\
2.5^{\prime} \text { dia. } \times 15^{\prime} \text { long } \\
\text { Total }\end{array}$ & $\begin{array}{r}12 \\
1 \\
13\end{array}$ & $\begin{array}{l}1.3 \\
2.1\end{array}$ & $\begin{array}{r}10 \\
2 \\
18\end{array}$ \\
\hline TOTAL & 35 & & 145 \\
\hline
\end{tabular}
(1) Data provided by the LANL IWOP (Ref 4)
(2) LANL has indicated that this volume is stored in seven
non-standard boxes (Ref. 13).

In the first option, it is planned that as this waste is retrieved and identified as SC waste, it will be put into temporary storage. Once the retrieval operations are completed (expected in FY97) all of the SC waste in storage will be disposed of via GCD at the same time. This disposal option will require appropriate environmental review before any disposal operations can proceed. The cost of this option is estimated to be $\$ 300,000$ (Ref 4).

The second option depends on the results of WAC exception negotiations with the WAC Certification Committee, WIPP Operations, and the state of New Mexico. Also, a transportation system must be developed to ship the waste from LANL to WIPP.

The third option requires the construction of a new facility that would allow the waste to be size reduced and repackaged in a WIPP acceptable form. For the small quantity of waste that is involved, this option is probably not economically feasible. 


\subsection{NTS}

\subsubsection{Waste Inventory}

NTS has ident ified three types of SC waste: oversized boxes, drums that contain unpunctured aerosol cans and liquids, and classified TRU waste.

The boxes have been retrieved and inspected, and do not meet Type A packaging requirements. This means that they cannot be shipped in TRUPACT as they are, but would require an overpack to meet the Type $A$ definition. The overpack needed for these boxes exceeds the WIPP WAC criterion of maximum package size. Also, the overpacks are too large to fit into TRUPACT. NTS has no facility to size reduce these boxes. The boxes are therefore considered SC because they are too large to be accepted by WIPP.

The drums are considered SC TRU jecause they contain unpunctured derosol cans and free liquids. These contents are not in compliance with the WIPP WAC. NTS has no facility to process these drums so that they can be certified.

NTS received and disposed of, via GCD, $140 \mathrm{~m}^{3}$ of classified TRU waste. This was a demonstration of GCD as a means of TRU waste disposal. Currently, evaluations are underway to demonstrate compliance with 40 CFR 191. An additional $44 \mathrm{~m}^{3}$ of classified TRU waste is in surface storage pending a decision to recycle matrix material.

SC waste inventories for NTS are shown in Table 2-4.

\subsubsection{Current Plan}

NTS has no waste processing facility. It is planning to use the SC drums to demonstrate GCD techniques for managing impractical to certify wastes. NTS will prepare an ADPP before they begin to dispose of this waste. GCD operations are expected to begin in FY89.

NTS will attempt to obtain an exception to WIPP WAC Waste Package Size Criterion for the oversized boxes. This criterion sets the maximum 
TABLE 2-4

NTS SC Waste Inventory

(as of $12 / 31 / 85$ )

\begin{tabular}{lccc} 
Waste Type & Packages & $\begin{array}{l}\text { Waste Vol.l } \\
\text { Pkg. }\left(\mathrm{m}^{3}\right)\end{array}$ & $\begin{array}{c}\text { Total } \\
\text { Vol. }\left(\mathrm{m}^{3}\right)\end{array}$ \\
\hline Oversized Boxes & \multicolumn{1}{c}{ Mixed Sizes } & 57 \\
Drums (1) & 229 & 0.208 & 48 \\
Classified in GCD(2) & 285 & Mixed Sizes & 140 \\
Classified in Storage (2) & 210 & 0.208 & 44 \\
TOTAL & 1009 & & 289
\end{tabular}

(1) Data provided by the NTS IWOP (Ref 5)

NTS has indicated in the ir 1987 IDB submittal that the SC drum inventory has decreased to 210 drums. This increase will have little effect on their plans.

(2) Data provided by NTS personne 1 (Ref 9)

package dimensions for waste that will be disposed of in WIPP. If the exception is not granted, the boxes will be disposed of via GCD. (See Section 3.5, page 33.)

Since NTS has no processing capability, it plans to dispose of its classified waste on-site via GCD. This will first recuire NTS to show compliance with 40 CFR 191.

\subsection{HANFORJ}

\subsection{Waste Inventory}

In the ir final IWOP, Hanford ident if ied twelve 55-gallon drums containing fissile material as SC waste. This waste is classified as SC waste because it exceeds the fissile material limits established by the WIPP WAC.

Hanford has identified $180 \mathrm{~m}^{3}$ of classified TRU waste that was received from RFP. This waste will require processing to remove the characteristic that makes the waste classified. 
Hanford also has an estimated $5 \mathrm{~m}^{3}$ of PCB-contaminated waste. While this waste is not considered SC waste, it will require incineration to be certified. Hanford does not have this on-site capability and plans to ship the waste to an off-site incinerator. The location of a mixed waste incinerator is part of the discussion in Section 3 of this report.

Therefore, the Hanford PCB-contaminated waste is shown in this report for completeness even though it is not considered SC waste by Hanford waste management.

Table 2-5 summarizes this information.

TABLE 2-5

Hanford SC Waste Inventory

(as of 12/31/35)

\begin{tabular}{|c|c|c|c|}
\hline Waste Type & Packages & $\begin{array}{l}\text { Waste Vol.l } \\
\text { Pkg. }\left(\mathrm{m}^{3}\right)\end{array}$ & $\begin{array}{l}\text { Total } \\
\text { Vol. }\left(\mathrm{m}^{3}\right)\end{array}$ \\
\hline $\begin{array}{l}\text { Drums } \\
\text { High Fissjle } \\
\text { Classif ied }(2) \\
\text { Drums - PCB }(2,3) \\
\text { Total }\end{array}$ & $\begin{array}{r}12 \\
831 \\
24 \\
867\end{array}$ & $\begin{array}{c}0.208 \\
\text { Mixed Sizes } \\
0.208\end{array}$ & $\begin{array}{r}2.5 \\
180 \\
5 \\
188\end{array}$ \\
\hline
\end{tabular}

17) Data provided by tr? Hanford IWOP (Ref 2)

(2) Data provided by Hanford Waste Management personne 1 (Ref. 14).

(3) Not considered SC TRU waste but included due to similar processing requirements as the INEL organic setups.

\subsubsection{Current Plan}

Hanford is planning to ship all SC, PCB-contaminated, and classified waste to WIPP for permanent disposal. Hanford will try to reach an agreement with WIPP that will allow the 12 drums or high-fissile material to be emplaced under an exception ruling. If such an agreement cannot be reached, the waste will be processed in the Waste Receiving and Processing facility (WRAP) and certified. The classified waste will be processed in WRAP to remove the classifying characteristics. WRAP is scheduled to begin operation in 1999. The PCB-contaminated waste will be shipped to an offsite location and incinerated. The location will be the same as the one selected for the INEL PCB-contaminated waste. 


\subsection{RFP}

\subsubsection{Current Plan}

Rocky Flats Plant has no interim storage and is planning to declassify its TRU classified waste prior to shipment to WIPP. This will require the capability to shred, cut, and melt these wastes to destroy the classified form. These capabilities are being implemented at RFP.

\subsection{SUMPIARY}

A summary of the waste volumes, facility requirements, scheduled start dates, facility capital costs, and processing costs required to implement the site plans is shown in Table 2-6. 
TABLE 2-6

Site Plan Summary

Site

INEL

Organics

$\mathrm{RH} /$ Lead-Lined

Oversized Boxes

Miscellaneous

HFEF Inserts

Total

ORNL

$\mathrm{RH}$

CEUSP

Misc. Cans

S. S. Wells

Total

LANL

Oversized Waste

NTS

Oversized Boxes

Uncert. Drums

Classified TRU

TOTAL

Hanf ord (3)

Drums-high fissile

Classified

Drums-PCB $(4)$

Total
Volume (mi) Requirements

1663

114

862

919

15

3573

\section{0}

1.7 WIPP WAC Exception

0.3 WIPP WAC Exception 1274

1.5 WIPP WAC Exception

145

ADPP

57 ADPP

48 ADPP

184 ADPP

289

2.5 WIPP WAC Exception WRAP

Start Facility Processing(1)

Date (SMillion) (SHillion)

$\begin{array}{lcc}\text { FY1999 } & \text { TBD (2) } & \text { TBD } \\ \text { FY 1991 } & 7.6 & \text { TBD } \\ \text { FY2000 } & 7.4 & \text { TBD } \\ \text { FY2000 } & 0 & \text { TBD } \\ \text { TBD } & \text { TBD } & \text { TBD } \\ & 22.2 & \text { TBD }\end{array}$

FY 1996

FY1994

FY 1994

FY1999

48.0
0

17

0

0

48.0

0

17

FY 1997

0

0.3

FY 1989

FY1989

FY 1987

T3D

TBD

TBD

TBD

TBD - TO Be Determined

ADPP - Alternate Disposal Practices Petition

(1) - Total life cycle processing costs.

(2) - INEL estimates the cost to be no higher than $\$ 7$ million. The actual cost will depend on the outcome of negotiations between INEL and the EPA concerning feed sampling requirements.

(3) - Zero facility costs are shown for WRAP because the facility will be primarily a non-special case $\mathrm{CH}$ certification facility and will be built regardless of its role as an SC facility.

(4) - Not considered SC TRU waste by Hanford but shown because it will require the same processing as the INEL organic setups. 


\subsection{POSSIBLE ALTERNATIVES TO SITE PLANS}

\subsection{INTRODUCTION}

This chapter will evaluate options that were and were not part of the site plans. These options are: the possibility of shipping SC waste to other sites for processing so that the waste can meet the WIPP WAC; the possibility of modifying current or planned facilities to process the waste; and the possibility of gaining a WIPP exception so that a small quantity of SC waste could be emplaced in WIPP without processing.

Figure 3-1 is a flow chart showing the decision-making methodology for the disposal of SC TRU waste. Waste is retrieved from storage and a determination is made as to whether the waste is certifiable or not. If it is certifiable, it is shipped to WIPP. If the waste is not certifiable, an exception to the WIPP WAC is considered. If the exception is not granted, the waste is processed in an on-site facility and shipped to WIPP. If no on-site facility is available, off-site facilities are considered. If a suitable off-site facility is identified, the waste is shipped off site, processed, and shipped to WIPP. If no off-site facility is available, the possibility of building a suitable on-site facility is examined versus the possiblity of using an $A D P$. If the new facility is justifiable on the basis of institutional issues, health, safety, and cost, the waste will be processed in the new facility, certified and shipped to WIPP. If all other options fail, an $A D P$ is used.

In developing possible alternatives to the site plans, several assumptions were made. These assumptions are:

1. The WRAP, WHPP, and the Transuranic Waste Facility (TWF) at SRP facilities will be built for reasons other than for processing SC TRU waste. Therefore, the capital costs of these facilities are not included in the economic analyses of this report.

2. The ATMX railcar will be available for as long as needed to transport SC TRU waste. 


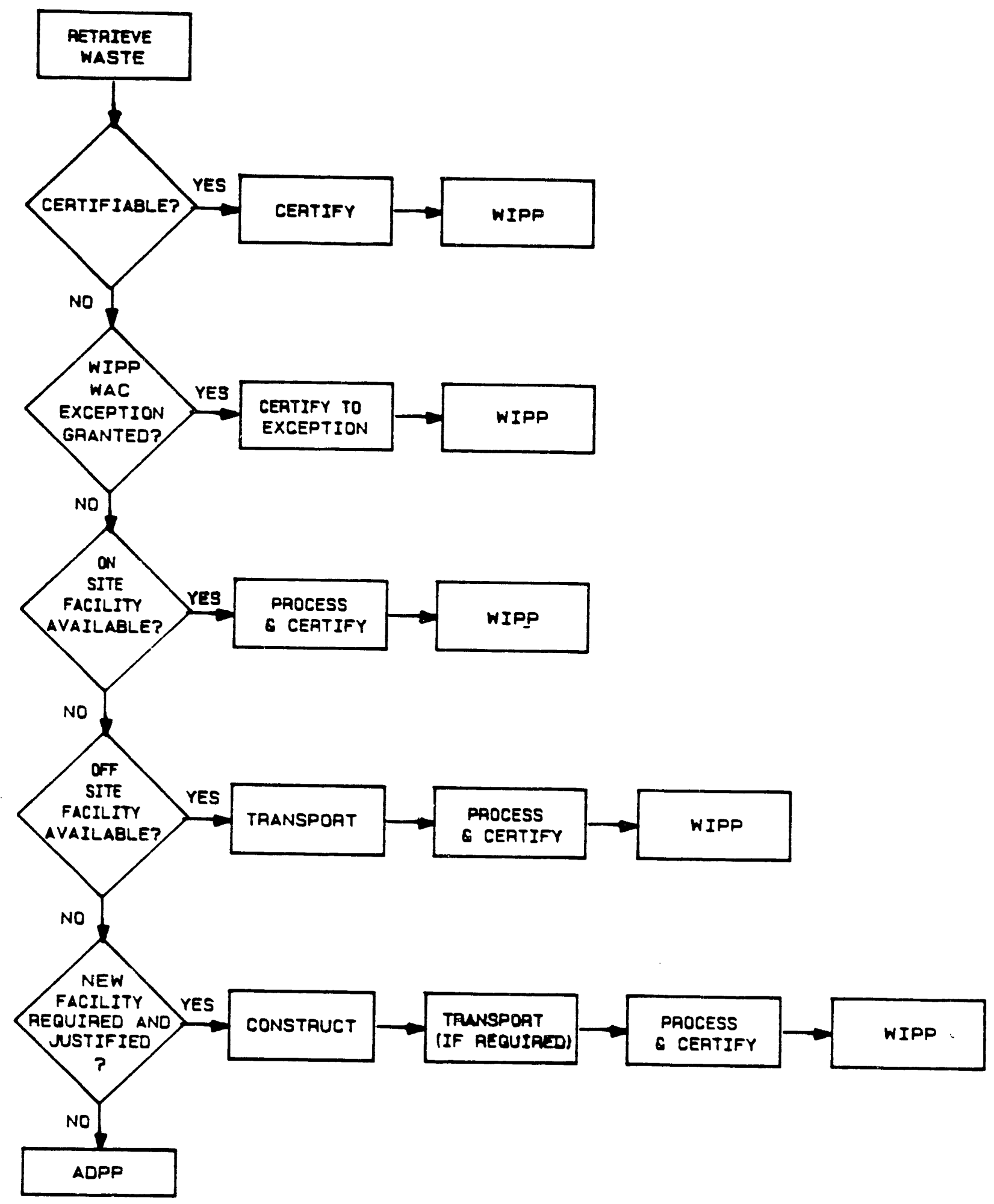

FIGURE 3-1: SPECIAL CASE LOGIC FLOW DIAGRAY 
3. Intersite shipments of SC TRU wastes are allowable as long as all applicable Department of Transportation (DOT) regulations are met.

4. The proposed TRUPACT-II has a waste volume limit of 36 55-gallon drums or two TRUPACT efficient boxes and has a payload weight limit of 12,000 1bs.

\subsection{INEL}

\subsubsection{Urganic Setups}

Tnis waste is neither certifiable nor eligible for an exception because of the PCB contaminants. The current INEL plan is to modify the PREPP facility so that it can incinerate SC waste, thereby destroying the hazardous chemicals that prevent the waste from being certifiable. The cust of this option is not fully defined, but is estimated to be no more than $\$ 7$ million for Research \& Developinent (R\&D), capital equipment, and equipluent inodifications (Ref. 7). The actual cost will depend on negotiations between INEL and the EPA concerning sampling and feed contrul requirements. If a statistical sampling program is accepted, then the costs would be greatly reduced.

An alternative to modifying PREPP is to ship the waste to another existing facility for processing. Three facilities that exist are the Treatment vevelopment Facility at LANL; the TSCA incinerator at the Oak Ridge Gaseous Diffusion Plant (ORGDP); and the Engine Maintenance, Assembly, and Visassembly (E-HAD) facility at NTS. The Treatment Development Facility contains an R\&D controlled air incinerator that will be used to incinerate most of LANL's combustible TRU waste.

The controlled air incinerator at LANL is designed to burn wastes with little or no non-combustible components. For most of its combustible wates, LAdl is expecting a 50 to 1 volume reduction upon incineration. The asn removal system for the controlled air incinerator is designed accordingly.

The INtL oryanic setups contain larye volumes of calcium silicate, a non-combustiole solidifying agent. This waste would only experience a 2 
to 1 volume reduction upon incineration. In the opinion of LANL personnel, the large fraction of non-combustible material would cause significant problems with the ash removal system. The LANL controlled air incinerator is, therefore, not a viable option for incinerating the INEL organic setups unless significant facility modifications are undertaker.

The transportation costs associated with processing INEL organic setups at LANL are shown in Appendix $C$. The costs for permitting the controlled air incinerator to process the organic setups and the costs for modifying the facility are not known.

The ORGDP TSCA incinerator is a new facility designed to burn mixed hazardous/radioactive wastes contaminated with uranium. The facility is permitted to incinerate both TSCA and RCRA regulated wastes. It is not, however, currently qualified to handle plutonium-contaminated materials. Also, some institutional issues regarding the state of Tennessee exist that may prohibit the processing and possible on-site disposal of off-site waste. Therefore, this option is somewhat speculative and the cost associated with qualifying the facility for plutonium handing are unknown. This option should be re-examined when some of the uncertainties are better defined. Appendix $C$ shows the transportation costs associated with this option.

The E-MAD is a facility at NTS that is currently planned to be used as a test bed for mobile waste processing systems. The developer of a system will set it up in the E-MAD hot bay and operate the system in a controlled environment. One such system that is anticipated to be tested is an electric pyrolyzer that will process mixed hazardous/radioactive wastes. This processing will combine mixed waste with silica and heat it in a controlled air enviroment to form a glass. The temperature and residence time will be sufficent to destroy the PCBs and other hazardous material, and the radioactive material will be immobilized in a glass matrix suitable for WIPP emplacement. 
Appendix $C$ shows that shipping waste to NTS for processing in the E-MAD could represent potential savings over the PREPP processing alternative. The facility modification and set-up costs are not known.

Table 3-1 summarizes the costs associated with the processing options.

TABLE 3-1

Organic Setup Cost Sumary

\begin{tabular}{lccc} 
Strategy & $\begin{array}{c}\text { Equipment } \\
\text { (\$Million) }\end{array}$ & $\begin{array}{c}\text { Transportation } \\
\text { (\$ Million) }\end{array}$ & $\begin{array}{c}\text { Total } \\
\text { (\$ Million) }\end{array}$ \\
\hline Process at INEL & Unknown $(1)$ & 1.28 & $1.28+$ Mod. \\
Process at LANL & Unknown & 3.35 & $3.35+$ Hod. \\
Process at NTS & Unknown & 5.12 & $5.12+$ Mod. \\
Process at ORNL & Unknown & 6.78 & $6.78+$ ilod.
\end{tabular}

(7) INEL has estimated that this cost may be as high as $\$ 7$ million depending on the feed sampling program that will be required.

Between the above alternatives, it is difficult to make a definitive choice. Each has certain advantages, disadvantages, and unknowns.

The LANL option has the advantage that the Treatment Development Facility is an operating facility and is expected to be operational through the scope of the TRU waste work off period. It has proven waste processing capabilities and is licensed to handle TSCA regulated substances. The major disadvantage is that LANL's ash removal system does not have a large enough capacity to be well suited to process the INEL organic setups.

The NTS option has the advantage that the site is receptive to accepting waste for processing. The cost of developing the process and permitting it for hazardous waste destruction will be incurred by the site and by 
the developer of the process. The disadvantage of this option is that it depends on some unknown quantities; for example, this process has not yet been proven to satisfy the needs of the organic setup waste form.

Another concern is that INEL's waste will not all be retrieved until the year 2006. Since the organic setups are comingled with the rest of the TRU inventory, it is impossible to say that all of the organics will be retrieved until this date. This means that the pyrolyzer would also have to be operational through the year 2006 . There is some doubt that this will be the case.

A potential solution to the problem posed by the 2006 retrieval date is to use the electric pyrolyzer on a series of waste processing campaigns as a mobile system. INEL can place the organic setups into temporary storage as they are retrieved from the waste storage pads. When a sufficient backlog has accumulated, the mobile system can be transported to INEL and the backlog can be processed. This option would entail some yet-to-be-determined processing and transportation costs. Also, some expenditures may be required to meet all applicable alpha containment, enviromental, safety, and permitting requirements. Using the mobile system would, however, eliminate the capital expenditures required to modify and permit PREPP as a hazardous waste incinerator.

The ORGDP option has the advantage that the incinerator is TSCA permitted. The disadvantage is that large uncertainties exist in regard to institutional issues and plutonium handling.

Processing at INEL has the advantage that no intersite shipments will be required to certify the waste. PREPP has the capacity to certify the waste but a TSCA permit and facility modifications may be needed.

Due to the uncertainties associated with the processing options, it is recommended that the decision as to where to process the INEL organic setups should be deferred to a later date, when some of the uncertainties are resolved. 


\subsubsection{Lead-lined}

The lead-lined waste cannot be certified in SWEPP because the current RTR system is not powerful enough to accurately examine the waste contents through the lead lining. An alternative to shipping this waste to WHPP is to install a more powerful Real-Time Radiography system in SWEPP. This option was evaluated and found to be not as cost-effective as shipping the waste to ORNL (See Appendix D).

Another alternative is to use the mobile RH NDA/NDE system. If this system is capable of examining the lead-lined containers, it would become the strategy INEL would use to certify its lead-lined containers. There would be no additional capital costs and no added intersite shipments. The problem with this option is that the lead-lined wastes are comingled with the rest of the INEL waste inventory. This means that all of the packages may not be retrieved unt il INEL completes its retrieval operations, scheduled for 2006. The RH waste is scheduled to be worked off by 1995. The decision as to the disposition of the mobile system subsequent to the RH waste being certified has not been made. If the mobile system is moved to another site, INEL would then have to ship all lead-lined packages to ORNL for certification. Appendix $D$ provides the detailed cost analysis for this evaluation. Table 3-2 summarizes this information.

TABLE 3-2

Lead-lined Package Cost Summary

\begin{tabular}{|c|c|c|c|}
\hline Strategy & $\begin{array}{l}\text { Equipment } \\
\text { (s Million) }\end{array}$ & $\begin{array}{c}\text { Transportation } \\
(\$ 11 \text { llion })\end{array}$ & $\begin{array}{r}\text { Tota } \\
\text { (s } 11 i 11 \\
\end{array}$ \\
\hline $\begin{array}{l}\text { Ship to WHPP } \\
\text { Cert ify at INEL } \\
\text { Cert ify Using RH NDA/NDE }\end{array}$ & $\begin{array}{l}0 \\
0.93 \\
0\end{array}$ & $\begin{array}{l}0.24 \\
0.09 \\
0.09\end{array}$ & $\begin{array}{l}1 . \\
0 .\end{array}$ \\
\hline
\end{tabular}




\subsubsection{Oversized Boxes}

INEL's plan for managing the 102 oversized boxes is to build a new facility to process them. The facility would have the capability to handle waste containers, size reduce large objects, immobilize liquid waste forms, and repazkage waste into new containers. The facility would not install a new NDA/NDE system, but rather would use the mobile NDA/NDE system developed by LANL. The capital cost for this alternative is estimated to be $\$ 7$ million (Ref 7 ).

An alternative to building a new facility is to ship the waste to another site for processing. Possible facilities include the WHPP at ORNL, the Transuranic Waste Facility at SRP, and the WRAP at Hanford. All of the se facilities are in their conceptual design phase and could be made to have large enough hot cells to hand le packages of this size.

An estimated $40 \%$ of the 102 oversized boxes are too large to be transported in TRUPACT. They are all transportable in the ATMX rail car. Using the ATMX for transportation would make the possibility of processing the waste at WHPP not cost-effective because ORNL does not have a rail spur. The cost of adding the spur is estimated at between $\$ 5$ inillion and $\$ 10$ million. This would leave WRAP and the Transuranic Waste Facility as viable options. Due to the shorter travel distance of the INEL-Hanford-WIPP option as compared to the INEL-SRP-WIPP option (2144 $\mathrm{mi}$. vs. $3850 \mathrm{mi}$.), processing the waste in WRAP is the most cost-effective. Shipping the waste to WRAP would save $\$ 6.6 \mathrm{million}$ compared to building a new facility at INEL (see Appendix E). A cost summary is shown in Table 3-3.

TABLE 3-3

Oversized Box Cost Summary

Strategy Equipment

Transportation (S Million) (S Million) (sMillion)

Total

Process in WRAP

Process at INEL

0

7.00

1.05

0.65

1.05

7.65 


\subsubsection{Miscellaneous SC Waste}

INEL has proposed that the small quantity of miscellaneous waste be processed in the same facility it proposes to process the oversized boxes in. The economic analysis of the size reduction facility shows that it is not cost-effective to build this facility; therefore, the miscellaneous waste will have to be processed elsewhere if the size reduction facility is not built. Several facilities will be capable of immobilizing this waste including WRAP, WHPP, and the TWF. The decision as to where the miscellaneous wast:e should be processed should be made at a future date when some of the uncertainties are resolved.

\subsection{ORNL}

The current plan for SC waste at ORNL is either to certify it for WIPP emplacement or to propose that it become the responsibility of the Federal Waste Management System. This is consistent with the goals of the program in that the TRU portion of this material is being permanently disposed. The plan is also consistent with the goals of this report because the TRU waste is scheduled to be shipped to WIPP and not disposed of in some other manner. Therefore, no change to the plan is recommended.

\subsection{LANL}

LANL has recommended that all of its SC waste be disposed of on site. This strategy was chosen because there is no transportation available to ship this waste off site. LANL plans to retrieve all of its waste by FY97 before it begins any GCD activities. At that time, an evaluation will be made on a case-by-case basis as to the disposition of each of the SC waste forms.

This report recommends that transportation alternatives be reevaluated in FY97. If a suitable system has become available at that time, the alternatives of seeking a WAC Certification Committee exception or shipping the waste off-site for certification should be examined. If no transportation system is available, the waste should be disposed of via GCD as planned. 


\subsection{NTS}

NTS has proposed that its SC waste be disposed of via GCD as a demonstration of that technology. This mode of disposal is dependent upon successful completion of a Performance Assessment as required by 40 CFR 191. Since waste will be required to demonstrate GCD, it is logical to use NTS waste for this purpose. Therefore, it is recommended that NTS use this waste as planned. It should be recognized, however, that the majority of the waste could be shipped to another site for processing, most likely PREPP at INEL. This option is available if NTS site management decides it is desirable.

\subsection{HANFORD}

Hanford proposes to certify the high fissile waste by exception. This plan is consistent with the goals of the program and therefore no alternative is recommended. Hanford plans to process its stored classified waste so that it is acceptable at WIPP. This plan is acceptable and no alternative was examined. The PCB-contaminated waste will be incinerated in an off-site facility. Potential incinerators include PREPP at INEL, the Treatment Development Facility at LANL, ORGDP at ORNL and E-MAD at NTS. The decision as to which off-site facility will be used should be made in conjunction with the INEL organic setups processing decision.

\subsection{RFP}

RFP is accelerating its efforts to declassify TRU classified waste and ship it to WIPP for disposal. Implementation of this declassification effort is planned for October 1987. This is consistent with the goals of the program so no alternative is recommended. 


\subsection{WORST CASE SCENARIO COST}

Figure 4-1 presents worst case scenarios for SC waste on a site-by-site basis. The costs presented wil! ue influenced by future analyses and decisions. The actual cost when the program is implemented could be dramatically lower than those presented. The intent of this analysis was to develop the upper limit of cost. The total shown for the upper limit case assumes all worst cases occur even though the worst cases may not be independent of each other. 


$$
\begin{aligned}
& \text { Worst Case Cost } \\
& \text { (\$ million) Assumption } \\
& \text { INEL }
\end{aligned}
$$

\section{NTS}
0
No longer considered SC waste

FIGURE 4=1: Life Cycie Management Cost for SC TKU Waste 


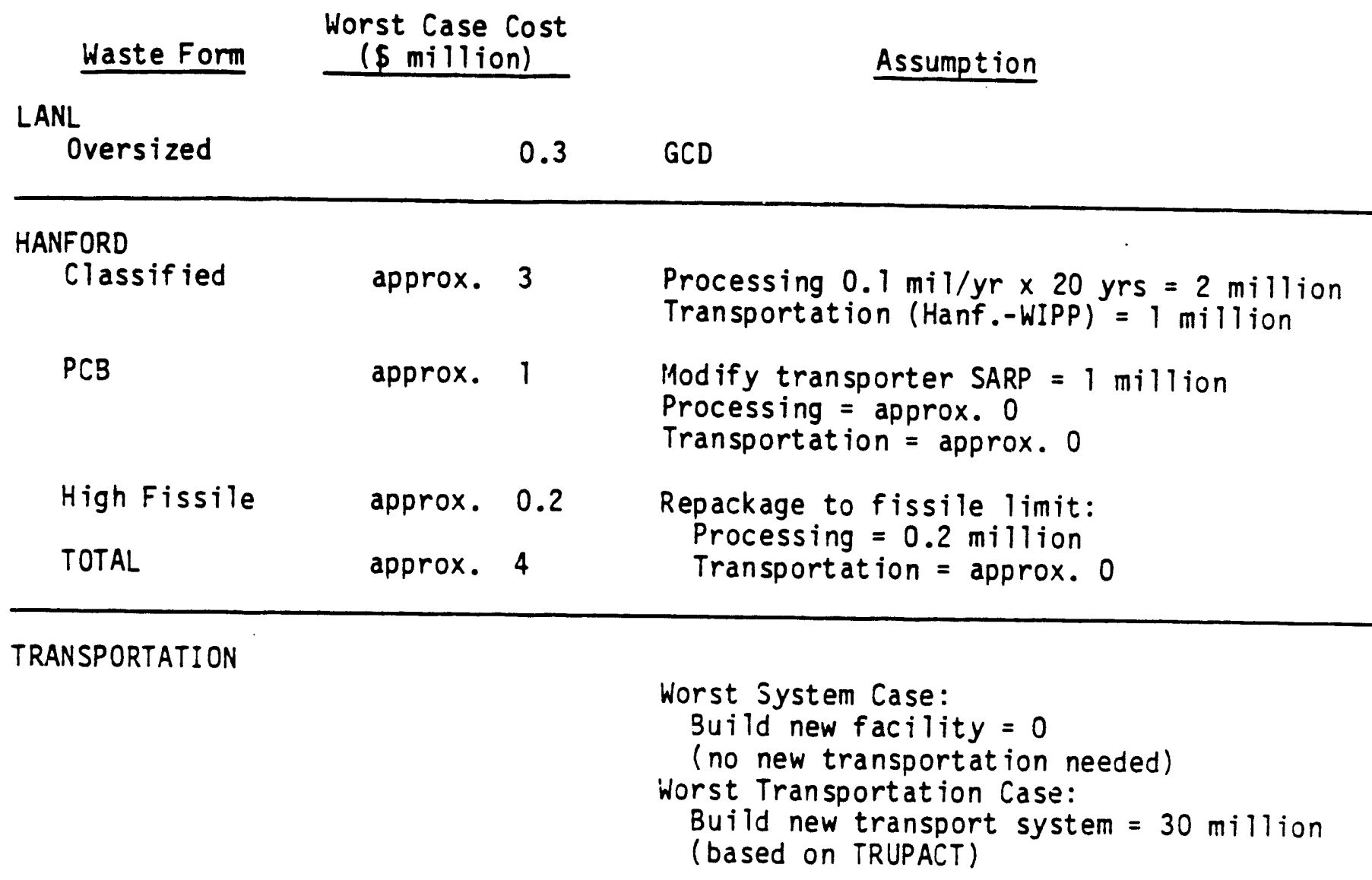

TOTAL

approx. 89

FIGURE 4-1: Life Cycle Management Cost for SC TRU Waste (Cont'd) 


\subsection{ISSUES AND UNCERTAINTIES}

\subsection{INTRODUCTION}

This section discusses the uncertainties associated with some of the analyses performed in this report. Uncertainties in the waste inventories and characteristics, technical areas, and institutional issues could have profound effects on the SC program. Resolution of these uncertainties will potentially alter some of the recommendations made in this report.

\subsection{WASTE VOLUMES}

The waste volumes reported in this plan are estimates made by the sites on the basis of their waste management records. These inventories are therefore somewhat uncertain and the true SC inventory will not be known until all stored TRU wastes have been retrieved.

\subsection{MIXED WASTE}

The EPA has been granted regulatory authority over the hazardous constituents of mixed hazardous/radioactive waste. This means that mixed TRU waste will have to to be generated, stored, handled, transported, and disposed of in manners consistent with both EPA and state hazardous waste regulations and DOE regulations and Orders. The effects of complying with RCRA are not yet fully known.

\subsection{ATMX AVAILABILITY}

It has been assumed that the ATMX rail car will be available for use for as long as needed. The ATMX license as a Type B package comes up for renewal every two years. A1so, the useful life of the ATMX may have to be extended. There is currently no other system capable of transporting the INEL oversized waste. Therefore, if the ATMX becomes unavailable, there may be no alternative but to build the proposed size reduction facility at INEL. As shown in Appendix $E$, this would cost $\$ 6.6$ million more than shipping the waste to Hanford for processing. 


\subsection{TRUPACT CONFIGURATION}

The TRUPACT configuration used in this report is the double contained, non-vented, rectangular shaped TRUPACT II. A redesign effort for TRUPACT is underway. The design that results from this effort may impact the transportability of some waste packages. Since the ability to transport waste to WIPP is sometimes a factor in designating waste as SC waste, the new TRUPACT design could influence the SC inventories. Inventory fluctuations could change some of the plans regarding SC TRU waste. 


\title{
6.0 SUMMARY OF RECOMMENDATIONS
}

\begin{abstract}
This section will sumarize the recommendations presented in this document. These recommendations are shown in Table 6-1, which lists the different types of SC waste that are found in the system, the proposed site plan, the recommended system plan, and a brief discussion of the differences between the two plans.
\end{abstract}




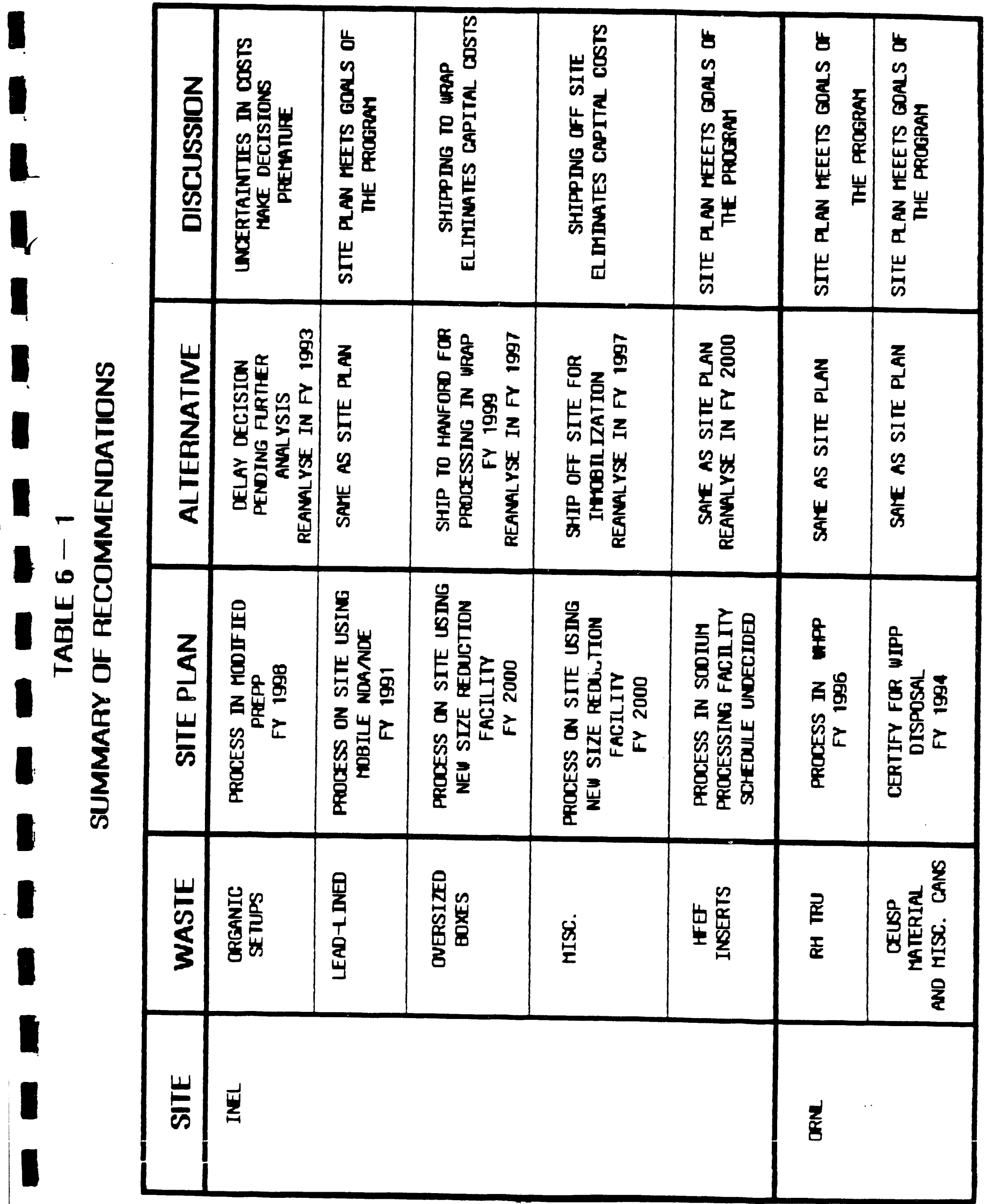




\begin{tabular}{|c|c|c|c|c|c|c|c|}
\hline 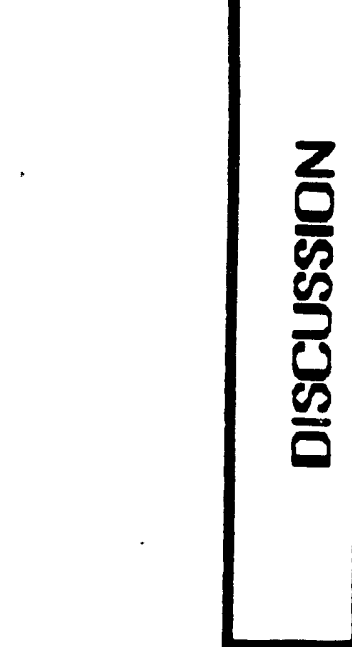 & 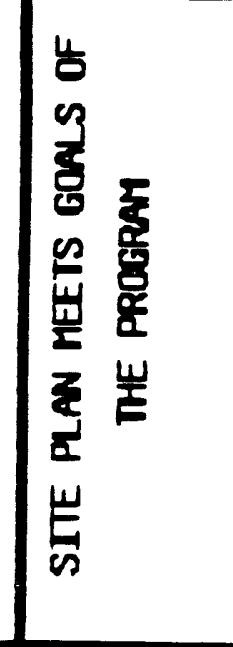 & 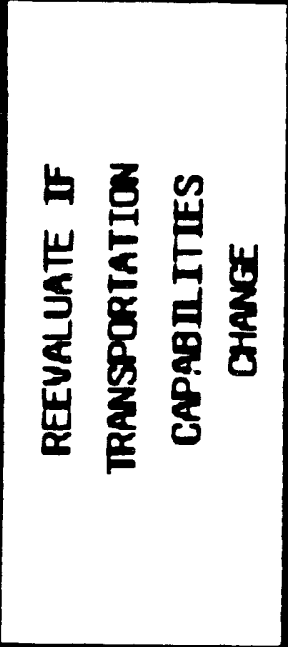 & 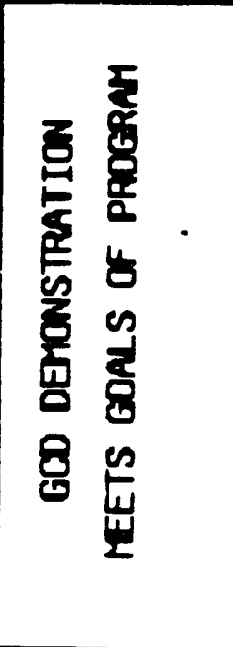 & 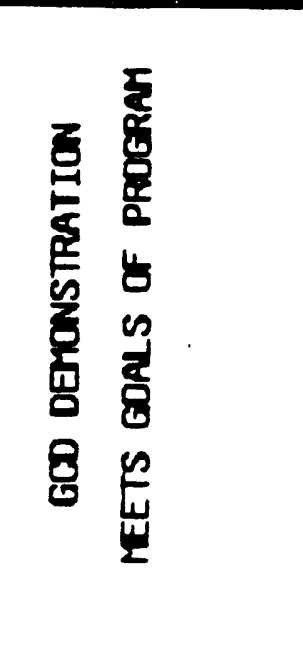 & 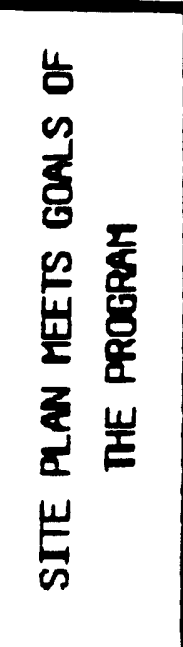 & 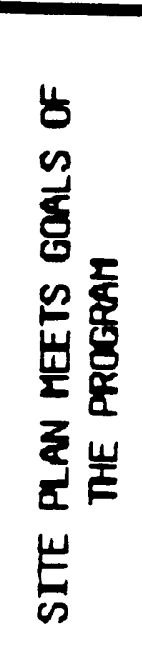 & 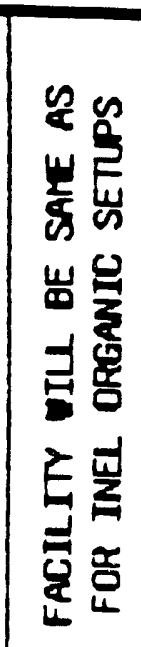 \\
\hline 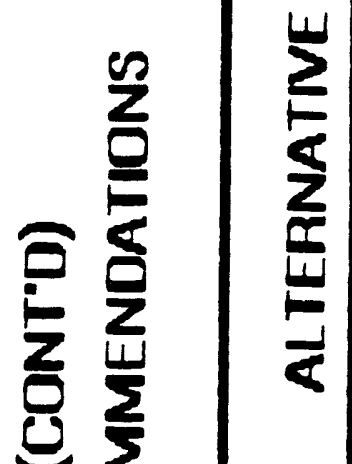 & 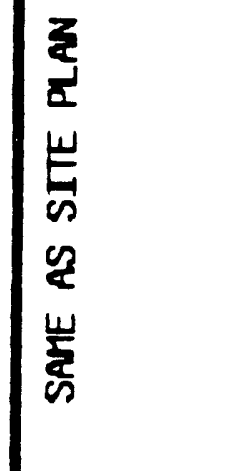 & 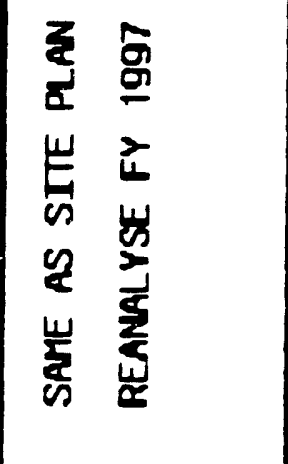 & 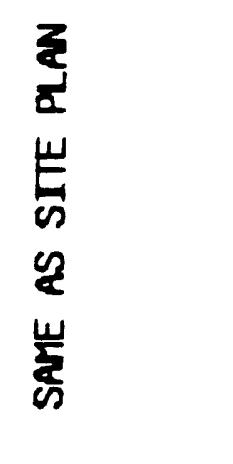 & 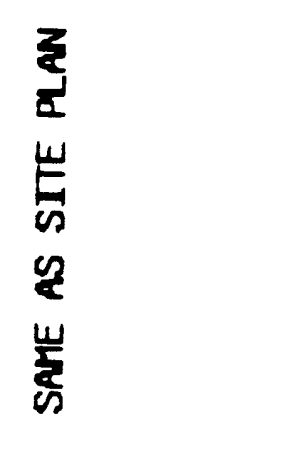 & 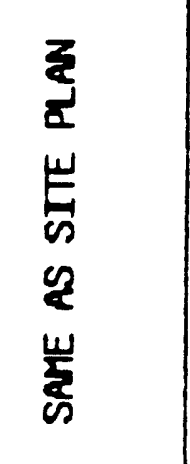 & 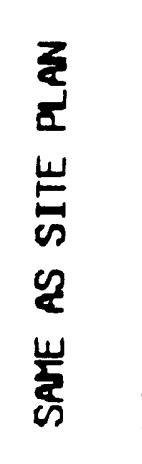 & 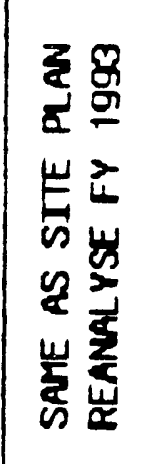 \\
\hline 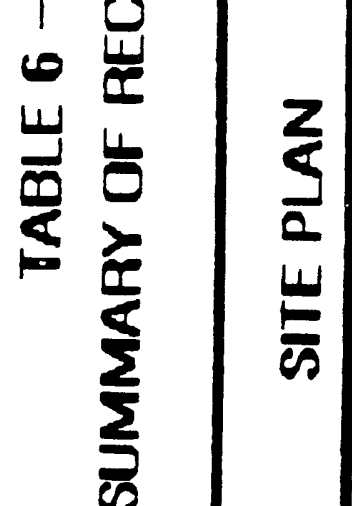 & 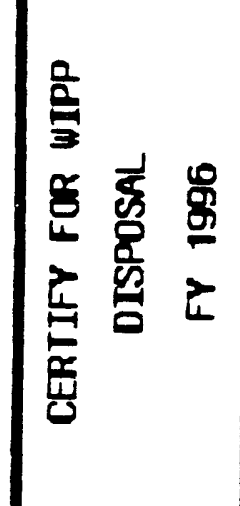 & 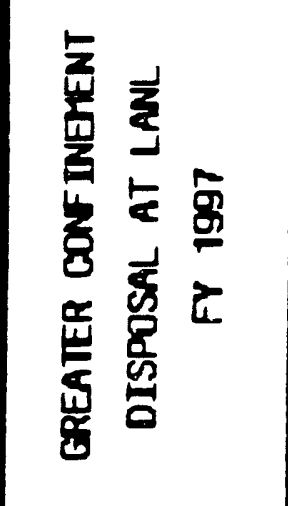 & 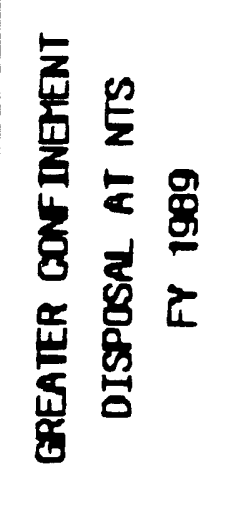 & 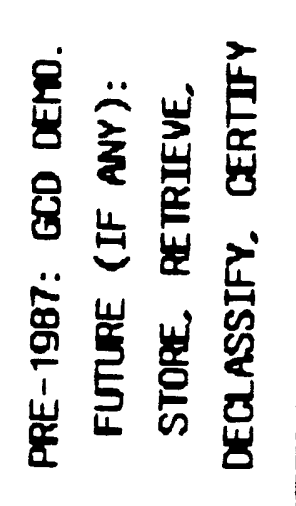 & 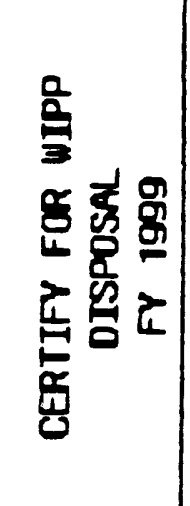 & 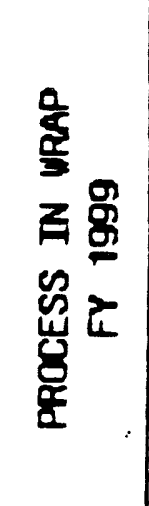 & 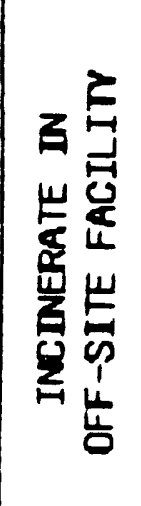 \\
\hline 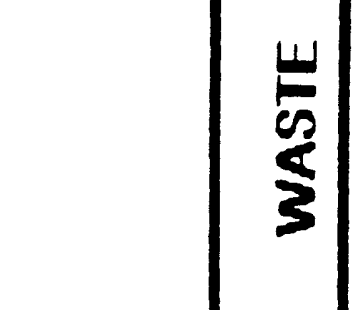 & 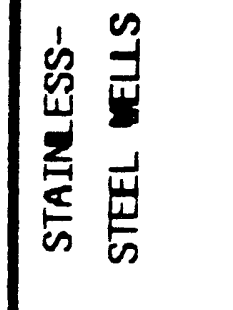 & 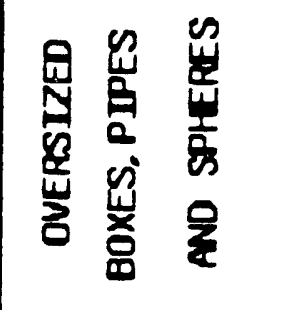 & 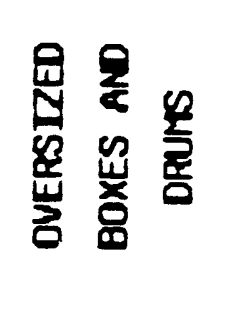 & $\begin{array}{l}\text { 易 } \\
\text { 悹 } \\
\text { d }\end{array}$ & $\frac{\varphi}{\frac{y}{2}}$ & 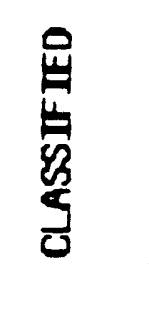 & 䍛 \\
\hline $\bar{\infty}$ & 产 & $\underline{3}$ & $\frac{\infty}{2}$ & & $\begin{array}{l}\stackrel{8}{8} \\
\text { 童 }\end{array}$ & & \\
\hline
\end{tabular}




\section{REFERENCES}

1) Idaho National Engineering Laboratory Transuranic Waste Inventory Work Off Plan, M. L. Bullock, September, 1986, EGG-WII-7142.

2) Hanford Site Transuranic Waste Inventory Work off Plan, September, 1980, KHU-W|l-PL-14P.

3) Inventory Wurk Off Plan for Transuranic Waste at Oak Ridye National Laboratory.

4) Final Inventury Work Uff Plan, J. L. Warren, A. E. Dross, August, 1986, LA-UR-862932.

5) Final Inventory Work Uff Plan for Hevada Test Site Transuranic Waste, August, 1986, RHII-6.

b) Environinental and Utner Evaluations of Alternatives for Long-Teri llanagelient of Stored INEL Transuranic Waste, December, 1979, U.S. Vepartment of Energy, UOE/ET-0081.

7) Alternative Evaluation for Idaho National Engineering Laboratory Rerivte-Mandled and Special-Case Transuranic Waste, W. H. Landinan, Jr., U. A. Peterson, October, 1986, WM-PD-86-023.

o) INEL presentation to JIU and UUE/AL personnel, "New Strategy for INEL Kemote-Handled/Special-Case TRU Waste," T. L. Clements, Jr., reoruary 2U, 1987.

9) Nevada Test site response to the Uraft Uefense Special Case Transuranic Waste Iinplementation Plan, April, 1987.

10) Vefense Kemote-Handled Transuranic Waste Cost/Schedule Uptimization Study, G. D. Pierce, et. al., November, 1986, UUE-JIU-UI7.

11) Uraft Lony-Kange laster Plan for Vefense Transuranic Waste Manayement, January, 1987.

1<) Tri-State (10tor Transit Company Tarrif Docunent for Transport of Radioactive Materials, Effective January 1, 1986

13) LANL response to the larch 1987 Draft of the Uefense Special Case Transuranic Waste Implementation Plan, April 13, 1987.

14) Hanford response to the Ilarcn 1987 Uraft of the Defense Special Case Transuranic Waste Implementation Plan, April 13, 1987.

10) Waste Cnaracterization for INLL Remote-Handled/Special Case Stored Transuranic Wastes, D. A. Peterson, November, 1985, WM-PD-85-014.

Ref. I 


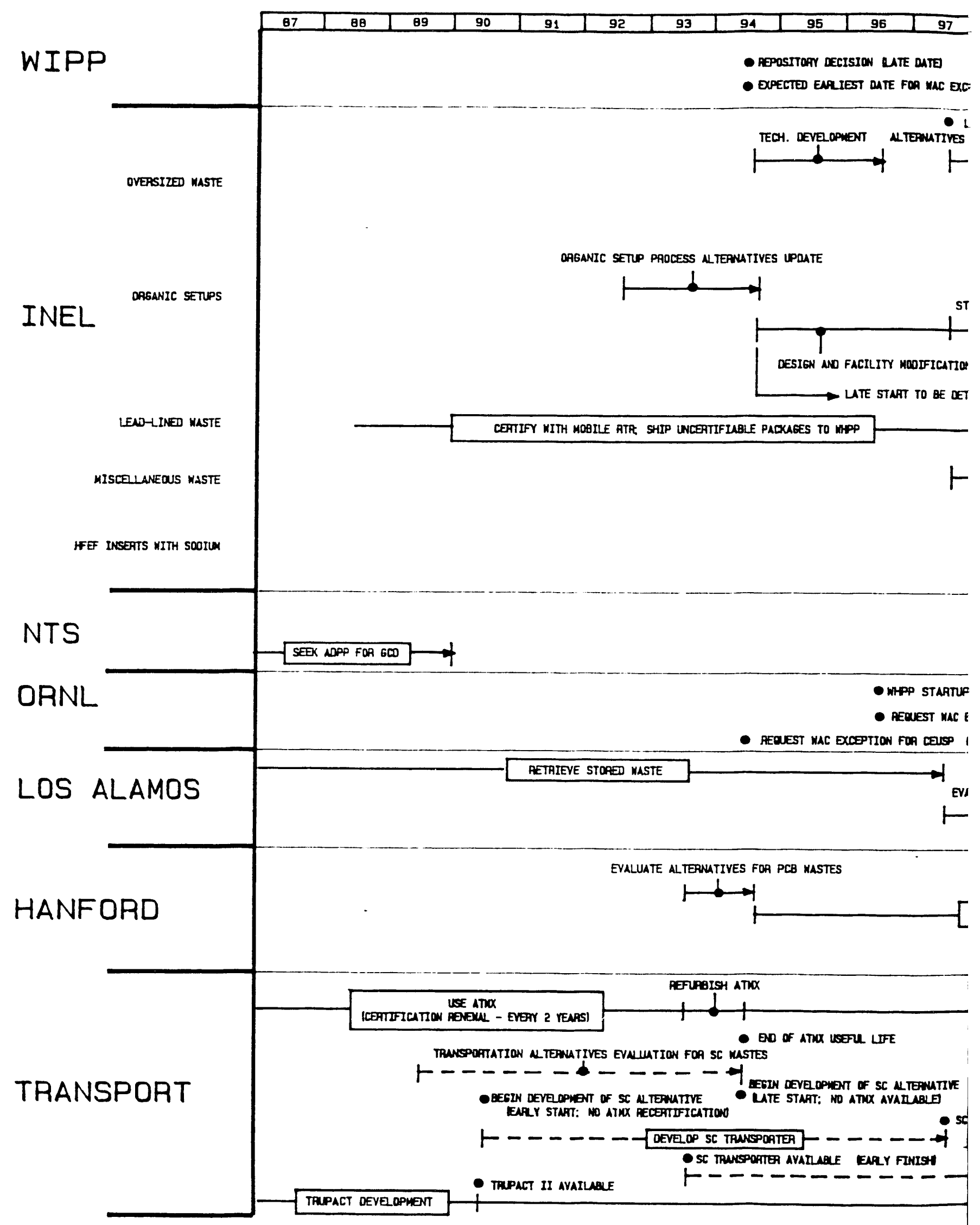

FIGURE A-1: SC 


\begin{tabular}{l|l|l|l|l|l|l|l|l|l|l|l|l|l|l|}
\hline 98 & 99 & 00 & 01 & 02 & 03 & 04 & 05 & 06 & 07 & 08 & 09 & 10 & 12 & 12 \\
\hline
\end{tabular}

now

TEST TRUSPORT AVATLAOLE MATE

VNULTION FOA OVERSILED MUSTE

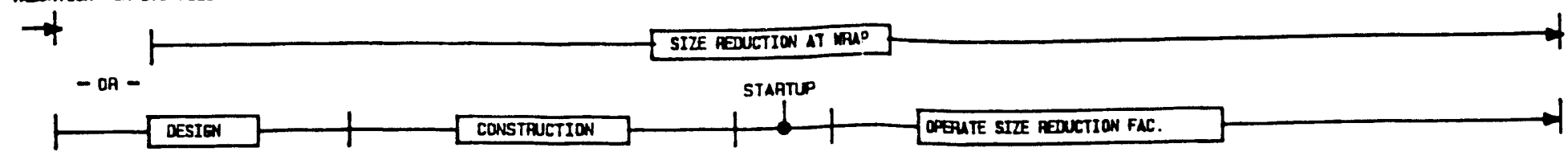

FTuP

1

MINED

- dNel complete stored maste rethieval

NTEAMTIVES EVAUATION FOR MISC. MASTE

$\stackrel{1}{1}$

- begin adpp , mac exception. oa paocessing

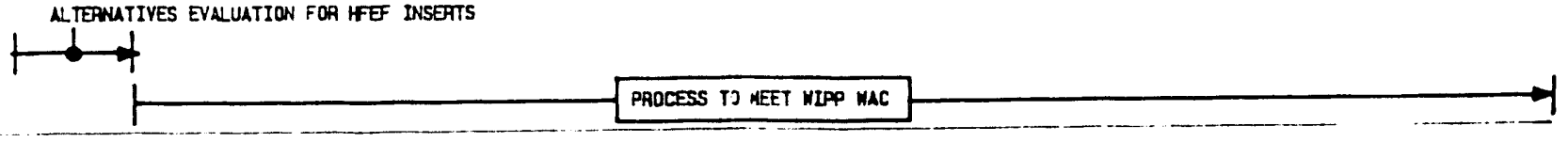

DPTION FQA MASTE IN STAIMLESS STEE MELS

MISC. CWN MLSTE

UMTE SC NLTEAMTIVES

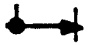

- initiate appo of exception hequest if redifed

IMPLEETT PCB SEECTED NTEAMTIVE

- map complete - SIzE reduction avaIlable

- hedest mac exception foh hIEH fISSILF MISTES

UEE RETPBISAE ATMX

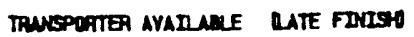

SC TAUSPOTIER OPJATIONS

TRAPACT OPERATIONS

MPLEMENTATION PLAN SCHEDULE 
APPENDIX B

TRANSPORTATION DATA

This appendix presents the freight cost data used to calculate the cost of shipping waste from one site to another, or from the sites to WIPP. These data were developed using Tri-State Motor Transit Company tariff rates (Ref 12). It should be understood that these rates are negotiable, and therefore the rates presented here are not actual. However, in order to quantify alternatives, these published rates were used.

Table B-1 gives the mileage and costs for shipping TRU waste under the assumptions that DOE will provide a trailer and that a second driver will be used.

TABLE B-1

Truck Freight Costs for Shipping TRU Waste

\begin{tabular}{|c|c|c|c|c|c|c|c|c|}
\hline From & To & Milage & $\begin{array}{r}\text { Trip Cost } \\
(\$ / \mathrm{mile})\end{array}$ & $\begin{array}{l}\text { Return Cost } \\
(\$ / m i \mid e)\end{array}$ & $\begin{array}{l}\text { Basic } \\
\text { Cost (\$) } \\
\text { (Rndtrip) }\end{array}$ & $\begin{array}{c}2^{\text {nd }} \\
\text { Jriver } \\
(.15 / \mathrm{mi} .)\end{array}$ & $\begin{array}{l}\text { Trailer } \\
\text { Credit } \\
(.05 / \mathrm{mi} .)\end{array}$ & $\begin{array}{c}\text { Total } \\
(\$)\end{array}$ \\
\hline $\begin{array}{l}\text { INEL } \\
\text { INEL } \\
\text { INEL } \\
\text { INEL } \\
\text { ORNL } \\
\text { NTS } \\
\text { LANL } \\
\text { INEL } \\
\text { Hanf }\end{array}$ & $\begin{array}{l}\text { ORNL } \\
\text { NTS } \\
\text { WIPP } \\
\text { LANL } \\
\text { WIPP } \\
\text { WIPP } \\
\text { WIPP } \\
\text { Hanf } \\
\text { WIPP }\end{array}$ & $\begin{array}{r}2131 \\
715 \\
1150 \\
850 \\
1303 \\
967 \\
300 \\
594 \\
1550\end{array}$ & $\begin{array}{l}1.56 \\
2.09 \\
1.90 \\
1.64 \\
1.88 \\
1.93 \\
2.85 \\
2.22 \\
1.84\end{array}$ & $\begin{array}{l}1.77 \\
2.09 \\
1.90 \\
1.64 \\
1.56 \\
1.93 \\
2.85 \\
2.22 \\
1.84\end{array}$ & $\begin{array}{l}7096 \\
3706 \\
4370 \\
2788 \\
4482 \\
3733 \\
1710 \\
2637 \\
5704\end{array}$ & $\begin{array}{r}639 \\
288 \\
345 \\
255 \\
391 \\
290 \\
90 \\
178 \\
465\end{array}$ & $\begin{array}{r}213 \\
96 \\
115 \\
85 \\
130 \\
97 \\
30 \\
59 \\
155\end{array}$ & $\begin{array}{l}7522 \\
3898 \\
4600 \\
2948 \\
4743 \\
3926 \\
1770 \\
2756 \\
6014\end{array}$ \\
\hline
\end{tabular}


COST ANALYSIS - PROCESSING INEL ORGANIC SETUPS

\section{Introduction}

This appendix shows the cost analysis that was performed to evaluate the alternative strategies for processing the INEL organic setups. Four alternatives were examined: processing the waste in the PREPP facility after modification; shipping the waste to LANL for incineration in the TDF; and shipping the waste to NTS for processing in the E-MAD; and shipping the waste to ORNL for processing the the ORGDP. There are three basic sets of costs that were accounted for in this analysis: transportation costs; equipment costs; and processing costs. It was assumed that each of the four alternatives incurred the same processing cost. If the processing costs become better defined, future analyses will be modified.

\section{Processing at INEL}

Equipment Modification:

INEL has projected that modifications

Unknown

of the PREPP facility may be required

to process this waste. INEL has stated that

this cost may be as high as $\$ 7$ million. This

includes permitting costs.

Transportation:

TRUPACT trips (volume limited):

7821 drums $\times \frac{1 \text { TRUPACT }}{36 \text { drums }}=218$ TRUPACT trips

12 boxes $\times \frac{1 \text { TRUPACT }}{2 \text { boxes }}=6$ TRUPACT trips

Total volume limited TRUPACT trips $=204$

(assumes no volume reduction (Ref 7 ))

TRUPACT trigs (weight limited):

$\frac{.208 \mathrm{~m}^{3}}{\text { drum }} \times \frac{29.5 \mathrm{~kg}}{\mathrm{~m}^{3}} \times \frac{2.2 \mathrm{lb}}{\mathrm{kg}}=\frac{335 \mathrm{lbs}}{\text { drum }}$ (Ref. 1)

$\frac{12000}{\text { TRUPACT }}$ ib $\times \frac{1 \text { drum }}{33516}=35 \frac{\text { drums }}{\text { TRUPACT }}$

7821 drums $\times \frac{1 \text { TRUPACT }}{35 \text { drums }}=224$ trips 
INEL boxes

$$
\begin{aligned}
& \frac{3 \mathrm{~m}^{3}}{\text { box }} \times \frac{385.3 \mathrm{Kg}}{\mathrm{m}^{3}} \times \frac{2.2 \mathrm{lb}}{\mathrm{kg}}=\frac{2543}{\mathrm{box}} \frac{\mathrm{lb}}{(\operatorname{Ref} .1)} \\
& \frac{12000 \mathrm{lb}}{\text { TRUPACT }} \times \frac{1 \text { box }}{2543 \mathrm{~Tb}}=\frac{4 \text { boxes }}{\text { TRUPACT }} \\
& 12 \text { boxes } \times \frac{1 \text { TRUPACT }}{4 \text { boxes }}=3
\end{aligned}
$$

Total weight limited TRUPACT trips $=227$

The box shipments are volume limited and the drum shipments are weight limited.

Note: It is assumed that INEL can manage the ir loading such that the heavy PREPP product drums can be shipped with lighter drums to maintain the average drum weight of $335 \mathrm{ib}$.

Total shipments $=224+6=230$

Freight Cost:

INEL to WIPP:

230 trips $\times \$ 4,500=\$ 1,058,000$

Loading/Unloading:

Load at INEL, unload at WIPP is part

of WIPP operating cost.

$$
230 \text { trips } x \$ 1,000=\$ 230,000
$$

Subtotal:

$$
\$ 1,058,000+\$ 230,000=\$ 1,288,000
$$

TOTAL

Processing at LANL

Equipment Modif ication:

Unknown

Transportation:

TRUPACT Trips:

$3,354,000$

LANL, NTS, and ORNL have much smaller waste

inventories than INEL. Therefore, it is assumed

that the se sites will not have lighter drums available

to load manage the heavy processed drums of waste. The

incineration residue will be immobilized to meet

the WIPP WAC on respirable fines. It is assumed that

a drum of immobilized residue will weigh 1200 lbs.

$\frac{12000 \text { ib }}{\text { TRUPACT }} \times \frac{1 \text { processed drum }}{1200 \text { TbS }}=\frac{10 \text { processed drums }}{\text { TRUPACT }}$

7821 drums $x \frac{1 \text { TRUPACT }}{10 \text { processed drums }}=782$ trips for drums

12 boxes $\times \frac{3 \mathrm{~m}^{3}}{\mathrm{bOx}} \times \frac{1 \text { drum }}{.208 \mathrm{~m}^{3}}=173$ drums from boxed waste

173 drums $x$ 1 TRUPACT $=18$ trips for boxed waste

10 processed drums 


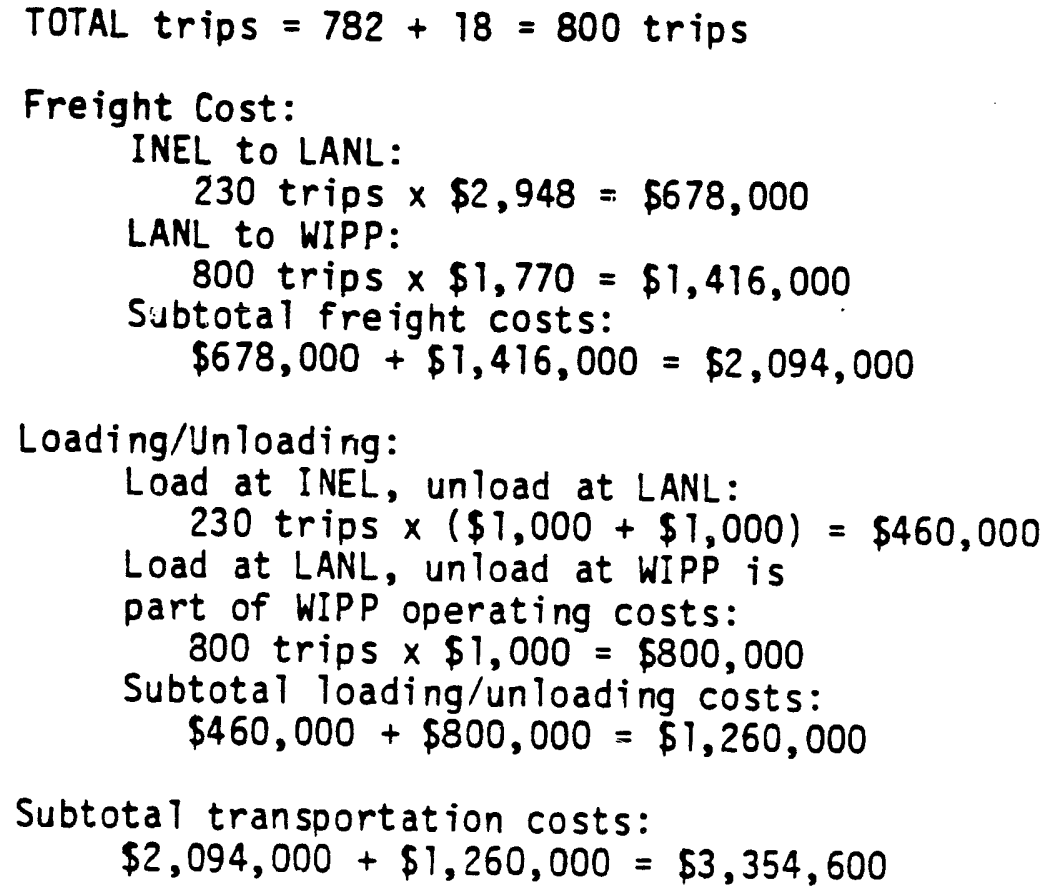

Equipment Modification:

Unknown

Transportation:

Freight Costs:

INEL to NTS:

$$
230 \text { trips } \times \$ 3,132=\$ 720,000
$$

NTS to WIPP:

800 trips $\times \$ 3,926=\$ 3,141,000$

Subtotal treight costs:

$\$ 720,000+\$ 3,141,000=\$ 3,861,000$

Loading/Unloading:

Load at INEL, unload at NTS:

230 trips $x(\$ 1,000+\$ 1,000)=\$ 460,000$

Load at NTS, Unload at WIPP is

part of WIPP operating costs:

800 trips $\times \$ 1,000=\$ 800,000$

Subtotal loading/unloading:

$\$ 450,000+\$ 800,000=\$ 1,260,000$

Subtotal transportation:

$\$ 3,861,000+\$ 1,260,000=\$ 5,121,000$

TOTAL

$\$ 5,121,000+$

Facility/Equipment :lod if ications 
Processing at ORNL

Equipment Modification:

Unknown

Transportation:

Freight Costs:

$6,784,000$

INEL to ORNL:

230 trips $\times \$ 7522=\$ 1,730,000$

ORNL to WIPP:

800 trips $\times 4743=\$ 3,794,000$

Subtotal freight costs:

$\$ 1,730,000+\$ 3,794,000=\$ 5,524,000$

Loading/unloading

Load at INEL, in load at LANL:

230 trips $\times(\$ 1000+\$ 1000)=\$ 460,000$

Load at ORNL, unload at WIPP is part of WIPP

operating costs:

800 trips $\times \$ 1000=\$ 800,000$

Subtotal loading/unloading costs:

$\$ 460,000+\$ 800,000=\$ 1,260,000$

Subtotal transportation costs:

$\$ 5,524,000+\$ 1,260,000=\$ 6,784,000$

TOTAL

$\$ 6,784,000+$

Facility/Equipment Modif ication

Table $C-1$ summarizes the costs for each alternative

TABLE $C-1$

Cost Summary

Alternate Processing Strategies for INEL Orgainic Setups

Equipment
Strategy $\quad \begin{gathered}\text { Transportation } \\ \text { (\$ million) }\end{gathered}$ Total

Process at INEL Unknown(1) $1.281 .28+$ Mod.

Process at LANL Unknown $3.353 .35+$ Mod.

Process at NTS Unknown $5.125 .12+$ Mod.

Process at ORNL Unknown $6.786 .78+$ Mod.

(1) This cost may be as high as $\$ 7$ million (Ref. 7).

Cenclusion

The uncertainties associated with the processing alternatives make it impossible to determine a definitive choice. Processing the wastes at 
LANL, NTS, or ORNL could possibly be more cost-effective than processing the waste at INEL, but the unknown facility modification costs make a definitive cost comparison impossible.

LANL has stated that its Controlled $A$ ir Incinerator (CAI) is not we 11 suited for incinerating the INEL PCB-contaminated wastes. The INEL wastes are roughiy 50\% inert material and the CAI is not designed to handle the large ash volumes that this waste would generate. Therefore, the LANL option should be dropped from consideration.

It is recommended that selection of a processing option be delayed pending further analysis. 
APPENDIX D

COST ANALYSIS - CERTIFICATION OF INEL LEAD-LINED WASTE

Introduction

INEL has identified that 44655 -gallon drums and seven $4^{\prime} \times 4^{\prime} \times 7^{\prime}$ boxes are impractical to certify due to the fact that the Real-Time Radiography (RTR) system in SWEPP is not powerful enough to accurately examine the package contents. INEL is recommending that these packages be certified with the mobile NDA/NDE equipment being utilized for the RH waste. Alternative strategies are to send the waste to ORNL for certification in the WHPP or to install a more powerful RTR system in SWEPP so the se packages could be examined in that facility. The on-site alternatives would incur smaller transportation costs than the ORNL alternative. Also, the modified SWEPP alternative would require expenditures for capital equipment. An important point is that while these packages are $\mathrm{CH}$ waste, the contents of these packages have high dose rates. Any packages that require processing will have to be sent to WHPP because PREPP is not designed to process high dose rate items.

Two basic costs were considered in this analysis; transportation costs and capital equipment costs. Processing costs were ignored because they would be the same for both options since processing will only occur in WHPP. 
Ship to WHPP for Certification

Capital Equipment:

Transportation:

TRUPACT trips (volume limited):

244,000

446 drums $x \frac{1 \text { TRUPACT }}{36}=12.4$ trips

7 boxes $\times \frac{1 \text { TRUPACT }}{2 \text { boxes }}=3.5$ trips

Total trips $=12.4+3.5=16$ trips

TRUPACT trips (weight 1 imited):

$\frac{120001 \mathrm{~b}}{\text { TRUPACT }} \times \frac{1 \text { drum }}{3151 \mathrm{~b}}=38.1 \frac{\mathrm{drums}}{\text { TRUPACT }}$

12000 ib $\times 1$ box $=4$ boxes

TRUPACT 259 TRUPACT

446 drums $\times \frac{1 \text { TRUPACT }}{38 \text { drums }}=11.7$ TRUPACT trips

7 boxes $\times \frac{1 \text { TRUPACT }}{4 \text { boxes }}=1.75$ TRUPACT trips

Total trips $=11.75+1.75=14$ trips

The shipments are volume limited.

Note: Package weight data provided by Ref. 15 .

Freight costs:

INEL to ORNL:

16 trips $\times \$ 7,522=\$ 120,000$

ORNL to WIPP:

16 trips $\times \$ 4,743=\$ 76,000$

Subtotal freight costs:

$\$ 120,000+\$ 76,000=\$ 196,000$

Loading/unloading costs:

Load at INEL, Unload at DRNL:

16 trips $\times(\$ 1,000+\$ 1,000)=\$ 3 ?, 000$

Load at ORNL, unload at WIPP is part of

WIPP operating costs:

16 trips $\times \$ 1,000=\$ 16,000$

Subtotal loading/unloading:

$\$ 32,000+\$ 16,000=\$ 48,000$

Subtotal transportation costs:

$\$ 196,710+\$ 48,000=\$ 244,000$

TOTAL

$\$ 244,000$

Certify at INEL (Modified SWEPP)

Capital Equipment (1)

High energy RTR $=\$ 715,000$

$\$ 930,000$

Design ( $30 \%$ of equipment) $=\$ 215,000$

Subtotal capital equipment:

$\$ 715,000+\$ 215,000=\$ 930,000$ 
Transportation:

Freight costs:

90,000

INEL to WIPP:

16 trips $\times \$ 4,600=\$ 74,400$

Loading costs:

INEL to WIPP:

16 trips $\times \$ 1,000=\$ 16,000$

Subtotal transportation:

$\$ 74,400+\$ 16,000=\$ 90,000$

TOTAL

$\$ 1,020,000$

(1) These costs provided by INEL (Ref 7).

Cert if $y$ at INEL (Mobile NDA/NDE)

Capital Equipment (2):

$\$ 0$

Transportation:

90,000

Freight costs:

INEL to WIPP:

16 trips $\times \$ 4600=\$ 74,000$

Loading costs:

INEL to WIPP

16 trips $\times \$ 1000=\$ 16,000$

Subtotal transportation:

$\$ 74,000+\$ 16,000=\$ 90,000$

TOTAL

$\$ 90,000$

(2) The equipment cost of using the mobile system is assumed to be zero because the system will be required to certify $\mathrm{RH}$ waste whether it is used for SC waste or not.

Comparing the costs of the three options shows that certifying the waste at INEL using the mobile system is less expensive than certifying it at WHPP or in a modified SWEPP. 


\section{APPENDIX E}

COST ANALYSIS - SHIPPING INEL OVERSIZED BOXES TO WRAP

\section{Introduction}

This appendix shows the cost analysis comparing the options of building a new facility at INEL to process oversized waste and shipping the waste to Hanford for processing in WRAP. The waste would be transported to Hanford in the ATMX rail car and size reduced to be transported to WIPP in TRUPACT. This analysis assumes that the processing costs at INEL would be roughly equal to the processing costs at WRAP. This analysis also assumes that the wastes will be repacked into 55-gallon drums for shipment to WIPP.

Process at INEL

Capital Equipment:

$\$ 7,000,000$

Transportation:

TRUPACT Trips:

$862 \mathrm{~m}^{3} \times \frac{1 \text { drum }}{.208 \mathrm{~m}^{3}}=4,145$ drums

650,000

4,145 drums $\times \frac{1 \text { TRUPACT }}{36 \text { drums }}=116$ trips

Average density for the waste in the oversized boxes is $\frac{123,2 \mathrm{~kg}}{\mathrm{~m}^{3}}$ (Ref. 1)

$\frac{123,2 \mathrm{~kg}}{\mathrm{~m}^{3}} \times \frac{2.21 \mathrm{~b}}{\mathrm{~kg}} \times \frac{0.208}{\text { drum }} \mathrm{m}^{3}=\frac{56.4 \mathrm{lb}}{\text { drum }}$

$\frac{12,0001 \mathrm{~b}}{\text { TRUPACT }} \times \frac{1 \text { drum }}{56.4 \mathrm{~Tb}}=\frac{212 \text { drums }}{\text { TRUPACT }}$

The shipments are volume limited.

Freight cost:

INEL to WIPP:

116 trips $\times \$ 4,600=\$ 534,000$

Loading/unloading:

load at INEL; unload at WIPP is part of

WIPP operating costs.

116 trips $\times \$ 1,000=\$ 116,000$

Subtotal transportation:

$\$ 534,000+\$ 116,000=\$ 650,000$

TOTAL

$\$ 7,650,000$ 


\section{Process at Hanford}

Capital Equipment:

Transportation:

Freight Cost:

INEL to Hanford ATMX:

$$
\begin{aligned}
& 1.17 \times 10^{5} \mathrm{~kg}(1) \times \frac{2.2 \mathrm{lb}}{\mathrm{kg}}=2.34 \times 10^{5} \mathrm{1b} \\
& \text { 2. } 34 \times 10^{5} 1 \mathrm{~b} \times \frac{\$ 14(2)}{1001 \mathrm{~b}}=\$ 33,000 \\
& \text { Hanford to WIPP: } \\
& 116 \text { trips } \times \frac{\$ 6,014}{\text { trip }}=\$ 698,000 \\
& \text { Subtotal freight costs: } \\
& \$ 33,000+\$ 698,000=\$ 731,000
\end{aligned}
$$

TUTAL

$\$ 1,049,000$

(1) Mass of oversized boxes. Data from INEL IWOP (Ref 1)

(2) AT.1X freight cost based on conservative assamptions made by J10 transportation management personnel.

(3) A loading analysis was not perfomed for the ATiMX. Instead, it was conservatively assumed that each box would be shipped separately. This represents the maximum number of ATMX snipments possible. 


\section{Conclusion}

The analyses presented above show that building a new processing facility at INEL is not as cost-effective as shipping the waste to Hanford for processing in WRAP. Processing in WRAP could save $\$ 6.6$ million $(\$ 7.6$ million - $\$ 1.0$ million).

Some of the assumptions used in the analysis of shipping waste from INEL to Hanford may be suspect. The ATMX freight rate of $\$ 14.00$ per $1001 \mathrm{~b}$. is an engineering assumption made by JIO transportation personnel. The analysis is not very sensitive to changes in this assumption. Even if the actual freight rate proves to be ten times greater than the assumed freight rate, the conclusions drawn by this report are still valid; shipping to Hanford will still be significantly less expensive than building a new facility at INEL. 

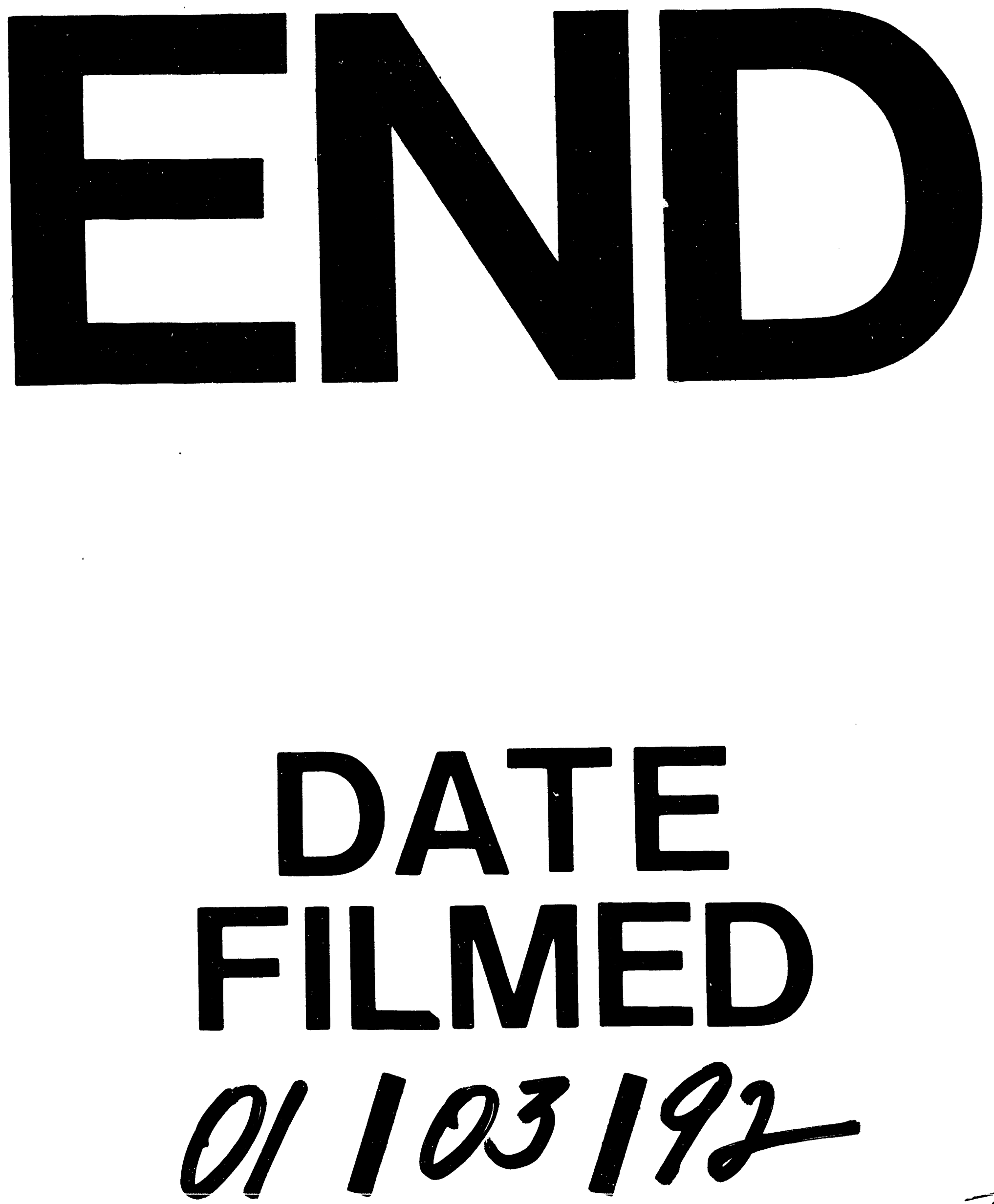
